\title{
The causal impact of material productivity on microeconomic competitiveness and environmental performance in the European Union
}

\author{
Florian Flachenecker ${ }^{1}$ D $\cdot$ Martin Kornejew $^{2}$
}

Received: 18 September 2017 / Accepted: 14 June 2018 / Published online: 3 July 2018

(c) The Author(s) 2018

\begin{abstract}
Interdisciplinary scholars and policymakers in the European Union (EU) claim that increasing material productivity improves the competitiveness of firms. However, the current evidence base has two main shortcomings. First, most studies fail to provide evidence beyond case studies, thus not considering dynamic effects and heterogeneity across firms, sectors, and countries. Second, they do not adequately take the endogeneity of changes in material productivity into account. In this paper, we investigate data from the Community Innovation Survey comprising over 52,000 firms across 23 sectors and 12 EU member states. Moreover, we take an instrumental variable approach to account for endogeneity. Our findings provide evidence for a positive and causal effect of material productivity improvements on microeconomic competitiveness for those firms that received targeted public financial support to realise eco-innovations. The effect tends to be limited to firms in certain materialintensive sectors and countries. We further show that such increases in material productivity reduce the firms' carbon dioxide footprint, thus achieving both economic and environmental objectives. Therefore, our findings provide the important policy insight that tailoring the availability of public financial supports to sector and country specific circumstances and those eco-innovations that increase material productivity is most promising in reconciling competitiveness and climate change mitigation objectives.
\end{abstract}

Keywords Material productivity $\cdot$ Competitiveness $\cdot$ Instrument $\cdot$ LATE $\cdot$ Ecoinnovations

JEL Classification C21 C26 $\cdot$ D24 $\cdot \mathrm{O} 31 \cdot \mathrm{Q} 32 \cdot \mathrm{Q} 56 \cdot \mathrm{Q} 58$

Florian Flachenecker

f.flachenecker@ucl.ac.uk

1 University College London, Institute for Sustainable Resources, London, UK

2 Kiel University, Department of Economics, Kiel, Germany 


\section{Introduction}

Achieving economic prosperity while staying within planetary boundaries is one of the main challenges of our time, thus being at the centre stage of contemporary discussions among academics, policymakers, and the private sector (e.g., Arrow et al. 1995; Rockström et al. 2009). One side of the spectrum argues that taking environmental aspects into account will come at the expense of economic activity; the opposing side claiming that considering environmental issues will unlock additional growth potential (e.g., Porter and Van Der Linde 1995; Jaffe et al. 1996). As part of this debate, materials have received increasing attention because of their vital role in production processes as well as their association with environmental pressures (UNEP IRP 2011; Bahn-Walkowiak and Steger 2015).

As such, materials feature prominently in policy making, especially in the context of the European Union (EU). One stream of material policies in the EU focuses on their strategic role as inputs to the production function (EC 2008, 2010). Another stream relates materials to environmental pressures (EC 2011a, 2015a). Irrespectively of different foci, material policies in the EU are motivated by combining both economic and environmental objectives. Specifically, material policies aim to increase the material productivity of firms which is claimed to improve firms' competitiveness and reduce associated environmental pressures. This assertion has gone hand-in-hand with substantial capital being directed into investment projects intending to improve material productivity. ${ }^{1}$

The existing literature finds that material productivity positively affects competitiveness (and associated measures) while reducing environmental pressures (Fh-ISI et al. 2005; Bleischwitz et al. 2009b; Schmidt and Schneider 2010; Ecorys 2011; Schröter et al. 2011; Bassi et al. 2012; AMEC and Bio IS 2013; Cooper et al. 2016; Gilbert et al. 2016). However, such investigations have two main shortcomings. First, they fail to systematically account for dynamic effects and heterogeneity across firms, sectors, and countries, as findings are largely based on case studies, thus limiting the results' transferability. Second, empirical studies lack to adequately address the potential endogeneity of material productivity, which could arise because material productivity is argued to increase firms' competitiveness, while more competitive firms are also more likely to be more material productive (Videras and Alberini 2000; Calantone et al. 2002; Aghion et al. 2005). Not addressing endogeneity causes coefficients to be biased and inconsistent (Angrist and Pischke 2009).

In this paper, we address the first shortcoming by considering the Community Innovation Survey (CIS) for the years 2006-2008, which comprises over 52,000 firms across 23 sectors of the so-called business economy and 12 EU member states. ${ }^{2}$ We address shortcoming two by applying an instrumental variable approach

\footnotetext{
1 For instance, investments in resource efficiency (and related areas) of EUR 14.9 billion between 2005 and 2014 and EUR 18.3 billion between 2006 and 2015 have been made by the European Investment Bank (EIB 2015) and the European Bank for Reconstruction and Development (EBRD 2015), respectively.

2 A list of all sectors and countries can be found in Tables 11 and 12 in "Appendix".
} 
using the availability of public financial support for eco-innovations (i.e., innovations with an environmental benefit) as an instrument for material productivity improvements. Interpreting our results in the spirit of the local average treatment effect (LATE) Theorem, our findings provide evidence for a positive and causal impact of increases in material productivity on microeconomic competitiveness for those firms that had an eco-innovation stimulated by public funding. However, the effect is limited to certain sectors and countries, raising the concern that not all firms, sectors, and countries are likely to benefit from increasing material productivity. We further show that such material productivity improvements also reduce the firms' carbon dioxide $\left(\mathrm{CO}_{2}\right)$ footprint, thus achieving both economic and environmental objectives for particular firms, sectors, and countries. Hence, we provide empirically robust evidence in support of eco-innovations, in particular those leading to material productivity improvements, since they are likely to be beneficial for firms' competitiveness (in particular in some material-intensive sectors and a few European economies) as well as firms' environmental performance.

This paper is structured as follows. Section 2 reviews the literature and identifies channels linking material productivity and microeconomic competitiveness. Section 3 describes the modelling approach and instrumentation strategy. Section 4 introduces the data and Sect. 5 outlines the results, including robustness checks. Section 6 provides evidence for the environmental benefits of material productivity increases, Sect. 7 discusses the findings, and Sect. 8 concludes.

\section{Microeconomic competitiveness and material productivity}

\subsection{Microeconomic competitiveness}

While macroeconomic competitiveness refers to countries, microeconomic competitiveness considers how firms compete with each other (Krugman 1994). Competitiveness on the firm level is typically defined as "the ability to compete in markets for goods or services" (Black et al. 2013). Accordingly, permanently competing in perfect markets, which is the definition's underlying assumption, requires firms to push average costs below the market price. However, this assumption entails perfect information, absence of transaction costs, homogenous goods, and price-taking behaviour which are often violated in practice, thus likely to change the type of competition (Aiginger 2006).

For a theoretical depiction of competitiveness to be practically relevant, factors beyond a firm's cost structure need to be considered. For instance, a firm would be more competitive compared to another if it offers a higher quality output at an equal (or lower) price (Ekins and Speck 2010). Moreover, information networks and continuous learning may shape the type of competition in the market in case the assumption of perfect information is violated (Maskell and Malmberg 1999), while barriers to entry, market power, and subsidies influence the ability to maintain market shares, too. Overall, in imperfect market settings, costs are only one determinant of firm's 'ability to compete'. Thus, a wider range of factors needs to be considered which can be grouped into internal (e.g., ability to reduce costs, innovations) and external determinants of 
competitiveness (e.g., market prices and structure, cost structure of competitors, subsidies, and information transmission).

To define an empirically estimable indicator, the literature frequently refers to outcome factors capturing the characteristics or 'symptoms' of competitive firms. There is no consensus in the literature on which factors best represent the outcome of competitiveness. Factors proposed include the ability to stay in business (Krugman 1994), generating high revenues and profits (Lehner et al. 1999; Siggel 2006; Ekins and Speck 2010), the expansion of firms' activities (Reinert 1995), improving single (labour or capital) or total factor productivity (Aiginger and Vogel 2015), increasing the number of employees (Chan et al. 2013), positive returns on invested capital (Snowdon and Stonehouse 2006), and exporting volumes in monetary terms (Siggel 2006; Dosi et al. 2015; EC 2015b).

Even though such outcome factors are measurable and available for empirical analyses, they lack one important aspect of competitiveness-its relative nature. Accordingly, a firm is more or less competitive compared to another firm (Krugman 1994; Siggel 2006). As such, an appropriate measure of competitiveness should benchmark the firm's performance to its competitors (Siggel 2006). While most of the above-mentioned outcome factors could be expressed in relative terms, only very few empirical analyses have taken the concept's relative nature into account (see Dechezleprêtre and Sato 2014). Most notably, Galdeano-Gómez (2008) define competitiveness as the sales ratio of a given firm against the total sales of all firms considered, and Triebswetter and Wackerbauer (2008) analyse competitiveness in the framework of market shares.

In line with these contributions, we chose firms' market shares based on turnovers to approximate competitiveness for two additional reasons. First, considering a firm's market share ensures a closed system, i.e., an improvement by one firm is equivalent to a loss for another firm. This prevents a situation in which all firms are falsely declared more competitive, while in fact, an equal change in a given indicator across all firms results in no firm changing its relative competitive stance. Second, in comparison with export or employment shares, turnovers are arguably closer aligned with the aforementioned definition of microeconomic competitiveness, i.e., the ability to compete in markets for goods and services (Black et al. 2013; Lehner et al. 1999; Siggel 2006; Ekins and Speck 2010).

\subsection{Material productivity}

Similar to labour productivity, material productivity describes the ratio between the output of a production process and the material inputs into this process (OECD 2007). Therefore, it provides information on the effectiveness by which output has been generated from material input (Dahlstrom and Ekins 2005; Syverson 2011). Material productivity (MP) can be expressed as

$$
\mathrm{MP}_{t, i}=\frac{Y_{t, i}}{M_{t, i}}
$$


where $Y$ represents output, $M$ material input ${ }^{3}\left(M_{t, i}>0\right), t$ the time dimension, and $i$ denotes the individual firm. Material productivity is a standardised measure used in empirical studies (e.g., Bruyn et al. 2009; Steinberger and Krausmann 2011; Wiedmann et al. 2015), among policymakers (Hinterberger et al. 2003; Bahn-Walkowiak and Steger 2015), and international organisations (e.g., UNEP IRP 2011; 2014; OECD 2016).

\subsection{Linking material productivity and microeconomic competitiveness}

By reviewing the literature, three channels can be identified linking material productivity and microeconomic competitiveness, inspired by the terminology used in the energy efficiency context (IEA 2014): (1) cost reduction; (2) risk mitigation; and (3) value creation. Table 1 summaries them, and a visual illustration can be found in Fig. 1 in "Appendix".

\subsubsection{Cost reduction}

2.3.1.1 Reducing input costs In a nutshell, if firms improve their material productivity, they are likely to reduce their absolute or relative material use. Since material costs account for $45 \%$ of the purchasing costs in the case of German manufacturing firms (KfW 2009; Statistisches Bundesamt 2011), for more than $50 \%$ of total costs for $27 \%$ of all EU firms in the manufacturing sector (EC 2011b), and for around 30\% in the chemical, paper, rubber and plastics, base metal, and wood sectors in the Netherlands (Wilting and Hanemaaijer 2014), reducing material costs is argued to enable firms to offer their goods and services at lower prices due to higher returns to asset (ROA) and sales (ROS) which essentially increases their competitiveness. ${ }^{4}$ While this represents a simplified transmission mechanism, more complex interactions are possible. For instance, reduced material costs could also be invested in R\&D and marketing activities or be used to increase wages attracting more productive employees-all likely to affect competitiveness other than through lowering prices.

Empirical evidence on the costs channel is limited to case studies for firms (FhISI et al. 2005; Schröter et al. 2011), sectors (Bassi et al. 2012; AMEC and Bio IS 2013), or countries (Oakdene Hollins 2011). Only few studies take a more holistic approach, thus accounting for dynamic effects and heterogeneity across firms, sectors, and countries. For instance, Bleischwitz et al. (2009a, b) find a positive and significant correlation between material productivity and several competitiveness

\footnotetext{
${ }^{3}$ Different indicators derived from economy-wide material flow accounting (EW-MFA) can be used as material input, including domestic material consumption, raw material consumption (also known as material footprint), and total material consumption. An overview of the various material flow indicators can be found in Flachenecker (2018). Using a production frontier approach is a suitable addition to EWMFA in deriving information on material productivity (or resource efficiency) (Hoang 2014).

${ }^{4}$ However, one study casts doubt on the meaningfulness of these figures, arguing that material costs typically do not only include the cost of raw materials, but all upstream labour, transportation, and storage costs. Bruyn et al. (2009) estimates the 'actual costs' of raw materials (excluding upstream value-added) to be approximately $3-6 \%$ of total costs.
} 


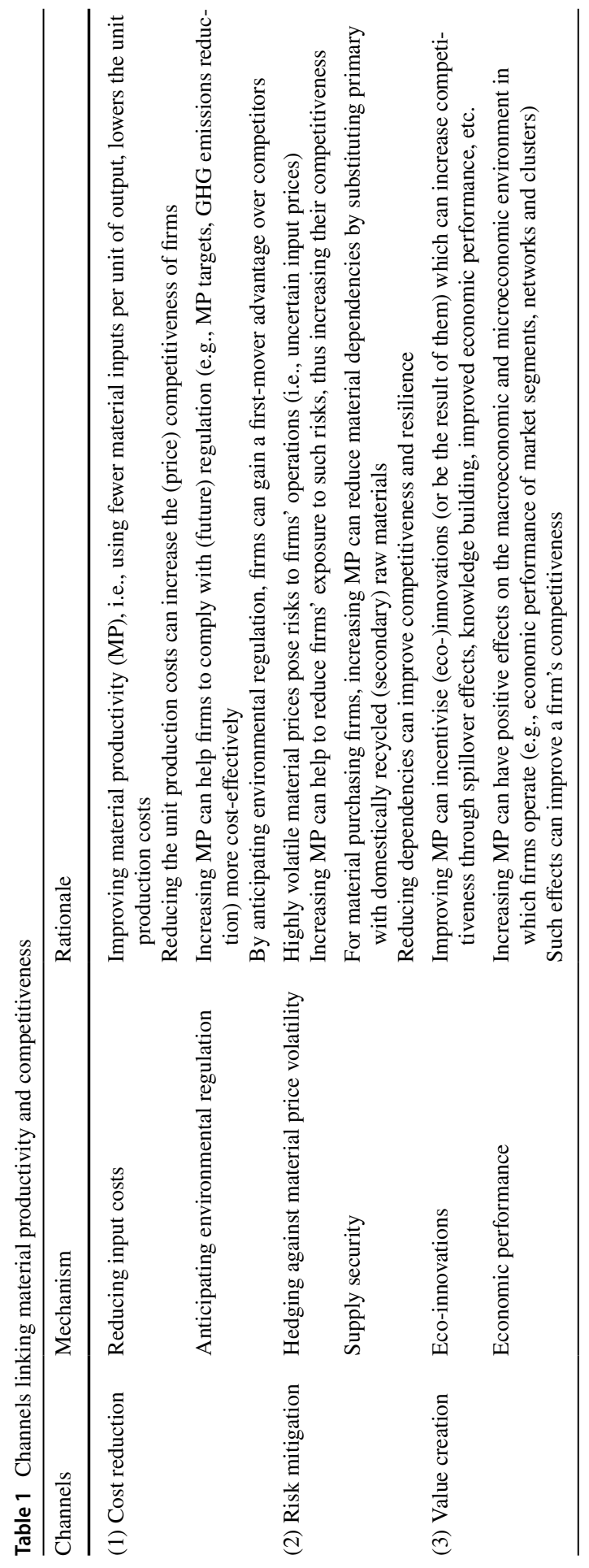


indices across the EU. The authors justify their findings by referring to the material cost channel. However, the authors acknowledge the possible problem of endogeneity in their analysis. Analyses on the country level that take endogeneity into account remain inconclusive about the relevancy of the cost channel (Flachenecker 2015, 2018).

2.3.1.2 Anticipating regulation Regulation might incentivise firms to grasp a firstmover advantage of innovating and thus becoming more competitive (Porter and Van Der Linde 1995). A more nuanced approach finds that innovations triggered by regulation might produce both 'winners' and 'losers' (Lankoski 2010). Recent empirical evidence suggests that environmental regulation increases patent applications (Rubashkina et al. 2015). Larrán Jorge et al. (2015) find that environmental performance has a positive and direct effect on competitiveness as well as an indirect impact on competitiveness through improved corporate image and marketing efforts.

Linking material productivity and environmental regulation (and thus indirectly competitiveness) is not immediate obvious. The link might be sequential; firms anticipating future environmental regulation, e.g., material productivity targets, GHG emission levels, increase their productivity in anticipation to comply with future regulation more cost-effectively, giving them a first-mover advantage (Gunningham et al. 2004).

\subsubsection{Risk mitigation}

2.3.2.1 Hedging price volatility Material price volatility leads to investment uncertainty (Pindyck 2007), a reduction of material use, and a decrease of industrial production (Zhao et al. 2013; Ebrahim et al. 2014). If price volatility is not hedged, firms' production cost may become volatile. Depending on the stickiness of the firms' prices, this could cause severe fluctuations of the cash flow, which in a worst-case scenario can lead to insolvency (AMEC and Bio IS 2013). By definition, increasing material productivity leads to a relative or absolute reduction of material use. This reduces the exposure of material price fluctuations on the firms' production costs, therefore, enabling firms to become more competitive and resistant to material price volatility.

2.3.2.2 Supply security Even if there is a broad consensus that most materials are physically abundant (Tilton 2001, 2003), the issue of criticality and supply security continues to be discussed from a strategic point of view (EC 2014a). If critical materials cannot be accessed and no immediate substitute or strategic reserves are available, production could be disrupted leading to a weakening of competitiveness of affected firms. Reducing the absolute material use by increasing material productivity could reduce the magnitude of the problem (Dussaux and Glachant 2015). 


\subsubsection{Value creation}

2.3.3.1 Eco-innovations Eco-innovations can comprise process, product, and system innovations (Kemp et al. 2013). Crucially, by improving the way materials are transformed into economic goods and services (while reducing their environmental repercussions), economic value is created. Increasing material productivity may be the result of an eco-innovation (Fischer and Brien 2012). At the same time, material productivity improvements can trigger additional (eco-)innovations, which are shown to positively contribute to a firm's economic success (Rennings and Rammer 2009).

Thus, productivity increases can result in innovative activity, which can increase the market share (EEA 2011), export activity (Lachenmaier and Wößmann 2006; Czarnitzki and Wastyn 2010), labour productivity (Hashi and Stojčić 2013), and incentivise future innovations in a virtuous cycle (Meyer 2011), all of which is positively associated with competitiveness (Porter 1990).

2.3.3.2 Economic performance Material productivity can increase economic activity (or be the result thereof), employment, productivity, and innovation activity in firms, networks, and clusters (Distelkamp et al. 2010; Ecorys 2011; Meyer 2011; Walz 2011; EC 2014b). On a sector level, Ecorys (2011) find that resource and thus material efficiency can lead to improvements in overall productivity. Moreover, Cooper et al. (2016) find (minor) employment effects of material efficiency strategies for the UK.

\subsection{Gaps in the literature}

The literature can be grouped according to the aforementioned channel. However, only general and indirect evidence is often available except for the material cost channel, which has been studied in greater detail. The overwhelming majority of these studies conclude that increasing material productivity leads to improvements in competitiveness (Fh-ISI et al. 2005; Bleischwitz et al. 2009b; Ecorys 2011; Schröter et al. 2011; AMEC and Bio IS 2013).

Nevertheless, the results are mostly based on simple statistical or correlation analyses, often using case studies for specific firms, sectors, or countries, not taking heterogeneity into account. For instance, AMEC and Bio IS (2013) base their results on a literature review, industry data, and case studies to estimate the aggregated saving potentials for sectors. Others take results from individual case studies to extrapolate the potential material savings to sectors (Fh-ISI et al. 2005; Schröter et al. 2011). Ecorys (2011) rely on nine resource-intensive sectors to draw countrywide conclusions, using literature reviews, consultations with stakeholders, qualitative surveys, and simple statistical analyses.

Thus, the current literature faces two main shortcomings which this paper aims to highlight. First, most studies do not take dynamic effects and heterogeneity across firms, sectors, or countries into account. Second, most empirical studies do not explicitly consider the potential problem of endogeneity of material productivity. 


\section{Modelling approach}

\subsection{The problem of endogeneity}

There are three potential sources of endogeneity—omitted variables, measurement errors, and simultaneity.

First, omitted variables are likely to be an issue in our analysis, as the factors determining competitiveness are numerous, as outlined in the previous section. Given that we base our analysis on survey data, we are limited to the information provided by the survey. ${ }^{5}$

Second, measurement errors occur frequently in surveys (Bertrand and Mullainathan 2001). Despite comprising mostly binary questions leaving relatively little room for systematic biases, they might still be present. Both omitted variables and systematic measurement errors may bias the OLS result in any direction.

Third, as outlined in detail in the previous section, the majority of the evidence suggests that increasing material productivity has a positive effect on microeconomic competitiveness. However, the causal effect can work in either direction (Galdeano-Gómez 2008; Sakamoto and Managi 2017):

On one hand, highly competitive firms with large market shares may be more likely to engage in voluntary environmental programmes, such as those increasing material productivity (Videras and Alberini 2000). Moreover, firms achieving competitiveness through innovation possess capabilities, knowledge, and willingness to learn, making them more likely to also engage in material productivity improvements (Calantone et al. 2002) or to increase environmental performance in general (Galdeano-Gómez 2008). This raises the concern that OLS estimates may overstate the true effect.

On the other hand, firms in highly competitive environments, where market shares are under constant pressure, firms are incentivised to innovate more frequently and achieve innovations of higher quality (Aghion et al. 2005). Hence, eco-innovations might be more prevalent among firms operating in markets, in which market shares_our measure of competitiveness - are particularly difficult to expand. This will inflict a downward bias on the OLS estimate.

Which of these two effects dominates, remains an empirical question to be investigated in this analysis. To address all three sources of endogeneity, we choose a two-stage least square (2SLS) instrumental variable approach with an exogenous instrument (Angrist and Krueger 2001). We argue that our approach is the most adequate in addressing endogeneity, since suitable alternative methods can produce biased and inconsistent estimates. For instance, it is shown that using lagged endogenous variables as instruments or estimating dynamic panels can easily infringe the exclusion restriction, thus leading to biased and inconsistent estimates (Kraay 2012; Panizza and Presbitero 2014; Reed 2015; Wagner and Hong 2016). In addition,

\footnotetext{
5 Since we did not obtain individual firm identification numbers, we were unable to merge the 20062008 wave with other waves or datasets. We leave the possibility of matching to future research.
} 
applying co-integration methods are mere statistical tools testing for 'causal' inference, but potentially lacking a robust foundation based on economic rationale (Wooldridge 2002). This is why we consider a 2SLS instrumental variable approach with an exogenous instrument as the most adequate method to estimate the causal effect of material productivity on competitiveness.

\subsection{Instrumentation strategy}

Instruments must comply with two conditions - they need to be relevant and exogenous. To satisfy the first condition, we need to identify a variable in the survey that correlates with material productivity innovations. Conveniently, the survey contains questions on the motives for introducing an eco-innovation, some of which have led to changes in material productivity. There are five possible answers, all of which arguably correlate with material productivity: (1) current or expected market demand for eco-innovations; (2) voluntary agreements within the sector; (3) existing environmental regulation; (4) expected environmental regulation; and (5) availability of public funds.

Second, the instrument has to be exogenous, i.e., it must not correlate with any variable absorbed in the structural error, in short, any variable that influences competitiveness but cannot be observed. For instance, the survey does not measure firms' ability and willingness to embrace change. However, firms that have (successfully) managed changes in demand and regulation in the past, thus increasing their competitive stance, have acquired knowledge and capabilities to cope with future changes as well (Malerba 1992; Caloghirou et al. 2004). Crucially, the prevalence of this so-called 'absorptive capacity' correlates with the firm's competitiveness, but simultaneously increases its probability of addressing current or future challenges by taking them as opportunities (Cohen and Levinthal 1990).

In fact, those challenges include current or expected market demand, voluntary agreements, and existing as well as expected environmental regulation. Thus, the first four variables are likely to select a particularly competitive pool of firms-i.e., those with high absorptive capacity — and thus are endogenous themselves, violating the exclusion restriction. This limits the potential instrument to the availability of public funds.

The availability of public funds, i.e., government grants, subsidies, or other financial incentives, is the most suitable instrument available in the survey for the following four reasons.

1. Legal considerations: by law, firms have equally access to public funding irrespectively of individual characteristics such as their past experiences of dealing with change, degree of competition in respective markets, and their competitive stance. ${ }^{6}$ The principle of non-discrimination applies regardless of the funds being

\footnotetext{
${ }^{6}$ However, sometimes specific groups of firms (especially SMEs) are given preferred access (Busom 2000; Blanes and Busom 2004). We will therefore show in the robustness section that restricting our sample to SMEs does not alter our findings.
} 
EU-wide, national, or local (EU 2012). Public funds cannot generally discriminate against any firm within the EU, regardless of which jurisdiction it is located in.

2. Equal opportunity: we expect any self-selection bias to be of minor concern, since there are numerous initiatives to equip firms with the necessary information and support to ensure equal opportunity for all firms to receive public funding. ${ }^{7}$

3. Funding considerations: public funds for eco-innovations do not directly increase the competitiveness of firms, but only cover (or refund) those costs that are directly associated with the eco-innovation. Therefore, any change in competitiveness followed by the use of public funds is likely to be directly due to the associated eco-innovation.

4. Previous application: this instrument has been used previously by Czarnitzki and Wastyn (2010) to estimate the impact of R\&D on export activity. The authors argue that export activity is unrelated to the selection of the R\&D subsidies. Thus, we chose the availability of public funds as our instrument.

\subsection{Model specification}

In our main model, we estimate the impact of changes in material productivity on changes in competitiveness. We start modelling competitiveness in levels:

$$
\ln \left(\mathrm{COMP}_{t, i}\right)=\gamma M P_{t, i}+\delta_{i}+\zeta_{s} t+\pi_{c} t+\boldsymbol{x}_{t, i} \boldsymbol{\beta}+e_{t, i},
$$

where $\ln \left(\mathrm{COMP}_{t, i}\right)$ depicts the log-level of firm $i$ 's competitiveness at time $t$ and $\mathrm{MP}_{t, i}$ its material productivity. $\delta_{i}$ are time-invariant firm-level fixed effects, $\pi_{c} t$ and $\zeta_{s} t$ country and sector specific trends, $\boldsymbol{x}_{t, i}$ is the vector of control variables, and $e_{i, t}$ is the structural error term.

Firm fixed effects $\delta_{i}$ cover those unmeasured components in corporate knowledge (e.g., human capital, business contracts, innovations, and management), absorptive capacity (e.g., firms' internal structure, information management, and retail structure), and the willingness to embrace change (e.g., know-how of past changes, branding, and market power) that affect the firm's competitiveness and are invariant over a 2-year period (Angrist and Pischke 2009). To control variable components, we additionally introduce different sets of observed firm-level characteristics, $\boldsymbol{x}_{\boldsymbol{t}, \boldsymbol{i}}$, in a later stage of the analysis.

We include country and sector specific time trends $\left(\pi_{c} t\right.$ and $\left.\zeta_{s} t\right)$ to pick up changing national regulation and market structures. Importantly, the latter will control how industry-specific competition evolves over time, being a major factor that affects firms' market shares externally.

First-differencing Eq. (2) removes time-invariant firm fixed effects and transforms country and sector specific time trends into simple country and sector dummies (Acemoglu and Johnson 2007; Dinkelman 2011):

$$
\Delta \ln \left(\mathrm{COMP}_{t, i}\right)=\gamma \Delta \mathrm{MP}_{t, i}+\zeta_{s}+\pi_{c}+\Delta \boldsymbol{x}_{t, i} \boldsymbol{\beta}+\varepsilon_{t, i}
$$

\footnotetext{
7 See for example the EU's small business portal (http://ec.europa.eu/small-business/finance/index _en.htm; last accessed on 1 November 2016), initiatives of national chambers of commerce and development banks.
} 
Following the 2SLS approach, the auxiliary model equation considers the impact of public financial support on material productivity improvements:

$$
\Delta \mathrm{MP}_{t, i}=\alpha_{0}+\alpha_{1} \mathrm{PFS}_{t-1, i}+\mu_{s}+v_{c}+\Delta \boldsymbol{x}_{t, i} \boldsymbol{\beta}+\varepsilon_{t, i},
$$

where $\mathrm{PFS}_{t-1, i}$ represents the availability of public financial support, $\Delta \mathrm{MP}_{t, i}$ are changes in material productivity, $\mu_{s}$ and $\nu_{c}$ are sector and country specific effects, and $\varepsilon_{t, i}$ is the error term. Equations (3) and (4) are estimated using 2SLS with errors robust against heteroscedasticity.

\section{Data}

We use the CIS from the European Commission for the years 2006-2008. The CIS is a harmonized and representative survey conducted in different countries across Europe to investigate the innovation activity in enterprises. It has been used extensively in academic research (Lööf and Johansson 2009; Czarnitzki and Wastyn 2010; Harris and Moffat 2011; Hashi and Stojčić 2013; Horbach and Rennings 2013; Horbach 2014). Our sample comprises over 52,000 firms across 23 sectors that the European Commission defines as the business economy (EC 2013) and 12 EU countries. ${ }^{8}$ Descriptive statistics on the main variables (including control variables) considered in our analysis are summarised in Table $2 .{ }^{9}$

\subsection{Competitiveness}

The CIS does not include any question that directly informs about the competitiveness of each firm. However, there is a question on the firm's total turnover for 2006 and 2008, i.e., market sales of goods and services including all taxes except VAT. Turnovers provide a general indication of the competitiveness of a firm (Lehner et al. 1999; Siggel 2006; Ekins and Speck 2010). Nevertheless, the absolute value undermines the relative nature of the concept of competitiveness (Krugman 1994; Siggel 2006).

For this purpose and as outlined in detail in Sect. 2, we measure competitiveness as the firm's market share, approximating the size of the relevant market by total turnover of the sector the firm operates in. ${ }^{10}$

$$
\mathrm{COMP}_{t, i}=\frac{\text { turnover }_{t, i}}{\sum_{\forall j \in s} \text { turnover }_{t, j}},
$$

\footnotetext{
8 The harmonized survey questionnaire of the CIS 2008 can be accessed via (last accessed on 28 March 2018) http://ec.europa.eu/eurostat/documents/203647/203701/CIS_Survey_form_2008.pdf.

9 We exclude all firms with zero turnover in 2006 or 2008 (5166 observations) and those outliers that increased their turnover within this period more than 15-fold (1113 observations). Including those firms with zero turnovers reduces the impact of material productivity but also leaves the overall outcome unchanged. Including firms with extraordinary turnover growth increases the coefficients magnitude.

${ }^{10}$ It should be noted that we do not consider sales of non-EU firms and un-surveyed EU-based firms since we have no information on them. However, both effects are expected to have a minor impact on the estimations presented in this paper, because such firms will distort only the denominator of the ratio which plays a subordinate role when looking at the first difference of the entire ratio.
} 


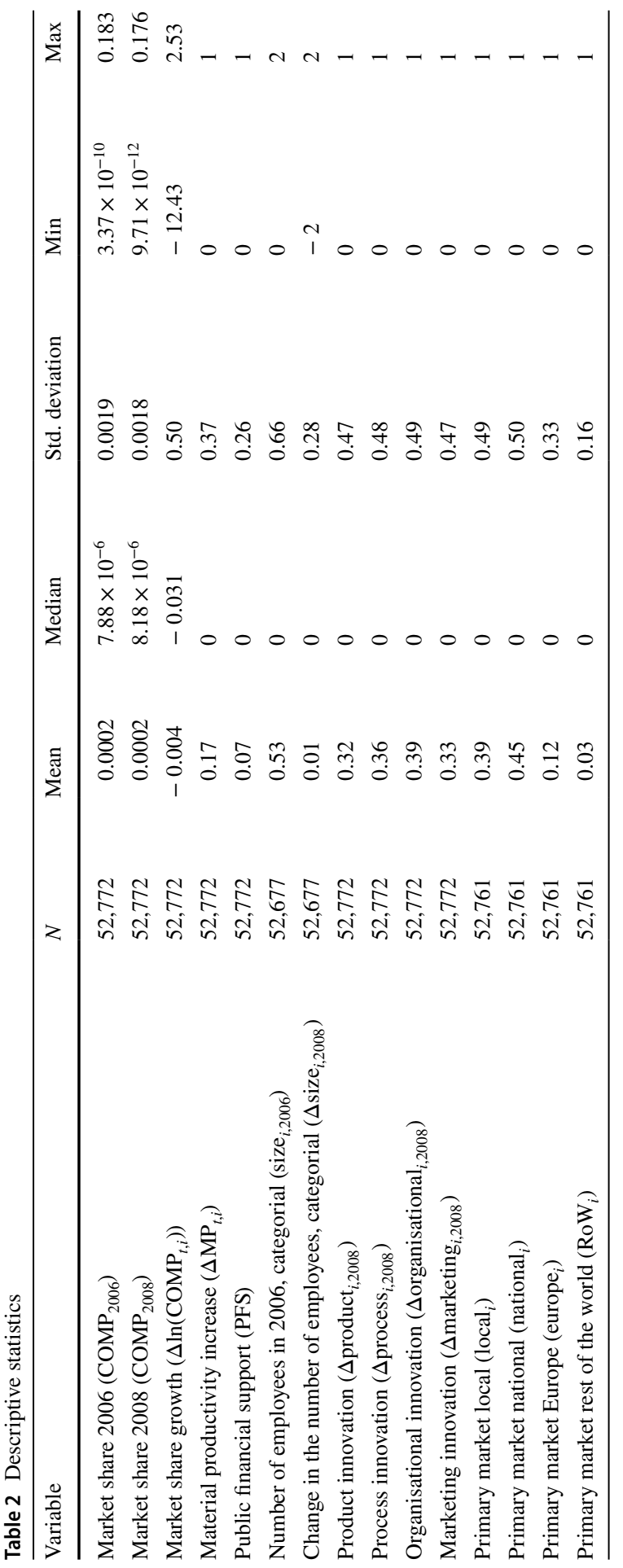


where the subscript $t$ stands for time (i.e., 2008 or 2006), while $i$ and $j$ index firms in sector $s$. This measure allows for cross section but also intertemporal comparisons.

In line with our main model in Eq. (3), we use natural logarithms and take the first difference of Eq. (5):

$$
\begin{aligned}
\Delta \ln \left(\mathrm{COMP}_{i, t}\right) & =\ln \left(\frac{\text { turnover }_{2008, i}}{\sum_{\forall j \in s} \text { turnover }_{2008, j}}\right)-\ln \left(\frac{\text { turnover }_{2006, i}}{\sum_{\forall j \in s} \text { turnover }_{2006, j}}\right) \\
& =\ln \left(\frac{\text { market share }_{2008, i}}{\text { market share }_{2006, i}}\right) \approx \frac{\text { market } \text { share }_{2008, i}}{\text { market share }_{2006, i}}-1 \\
& =\frac{\text { market share }_{2008, i}-\text { market share }_{2006, i}}{\text { market share }_{2006, i}}
\end{aligned}
$$

Thus, estimated regression coefficient may be interpreted as approximated marginal effects on market share growth.

\subsection{Material productivity}

Data on changes in material productivity are directly available in the CIS, though the 2006-2008 wave is the only one containing an explicit question on material productivity improvements. The question is framed within the context of the environmental benefits resulting from an eco-innovation that firms had between 2006 and 2008. Note that the survey provides no information about the actual levels of material productivity. Instead, the binary choice question asks firms whether or not they reduced their material use per unit of output, ${ }^{11}$ i.e., increased their material productivity, as a result of an eco-innovation during this period.

In addition, the survey does not provide any information on which types of materials (metals, minerals, etc.) are linked to the change in material productivity or which specific type of eco-innovation resulted in an increase in material productivity. Regarding the latter point, the question refers to the types of innovations asked in previous parts of the survey, namely, a product, process, organisational, or marketing innovation. Thus, we excluded 16 firms that have not had any of such innovations, but still answered to the questions on eco-innovations. As shown in Table 2, $17 \%$ of all firms in our sample had an eco-innovation that led to a material productivity increase.

Furthermore, the CIS questionnaire relates the material productivity improvements to the production of goods or services within the firm. While no additional details are provided, this suggests that the CIS only considers those changes in material productivity that (1) relate to the production (not consumption) side and (2) take place within the firm, thereby excluding possible improvements along the materials' supply chains taking place outside the firms' gates.

\footnotetext{
11 While there are no further details provided in the CIS besides the question as to whether a firm has "reduced material use per unit of output" (variable code name ECOMAT), it seems reasonable to assume that both variables (i.e., material use and output) are considered in units of mass or unit quantities.
} 


\subsection{Public financial support}

As with material productivity improvements, data on public financial support are available only as a binary variable. It turns 1 whenever public funds were available to a firm that had an eco-innovation between 2006 and 2008. As reported in Table 2, such firms make up $7 \%$ of our sample. However, they are well distributed across countries and sectors and mirror total sample properties regarding firm sizes and market orientation. Table 13 in "Appendix" presents estimates from regressing $p u b$ lic financial support (PFS) on the full set of country and sector fixed effects, and central firm characteristics such as size, market activity, and export orientation. Provided with such a large number of observations, we are able to detect significant distributional disproportions. Importantly though, even this rich set of controls explains a mere $3 \%$ of the instrument's total variation (unadjusted). This leads us to conclude that our instrument covers a broad and diverse cross section of firms.

\subsection{Local average treatment effect (LATE)}

The causal relationship identified by an instrumental variable approach relies on the variation caused by the instrument. Since our endogenous variable is binary, while treatment effects are likely to be heterogeneous across firms, our results need to be interpreted in the spirit of the LATE theorem (Imbens and Angrist 1994; Angrist et al. 1996). The LATE theorem has been used previously in an instrumental variable setting in which the instrument is binary (Lachenmaier and Wößmann 2006). In our case, the estimate in Eq. (3) relies on the variation in competitiveness caused by material productivity increases that were triggered by the availability of public funds and would not have been implemented without such funds. Thus, essentially, we are evaluating whether those funds have been used successfully.

According to Imbens and Angrist (1994) and Angrist et al. (1996), one additional condition to the ones described in the previous section need to be met to make causal inference in this setting-monotonicity. The direction of the effect of public financial support on the likelihood of changing material productivity should be the same across all firms. This seems reasonable in our case because public funding is only granted to firms if they use the resources to generate an eco-innovation, while it should not prevent firms from increasing their material productivity.

\section{Results}

We start by presenting the first-stage model (Eq. 4). Table 3 indicates that firms motivating their eco-innovation by the availability of public funding have a $26 \%$ higher chance to improve their material productivity compared to firms motivating their eco-innovation differently or not eco-innovating at all.

The instruments are valid and strong as documented by the coefficient's significance, a Kleibergen-Paap Wald $F$ statistics well above 10, and the rejection of under 
Table 3 First-stage results

\begin{tabular}{ll}
\hline PFS $_{i}$ & $\begin{array}{l}0.2612 * * * \\
(0.0077)\end{array}$ \\
Country dummies & YES \\
Sector dummies & YES \\
$\begin{array}{l}\text { Kleibergen-Paap rk Wald F statistic (weak } \\
\quad \text { identification) }\end{array}$ & 1137.96 \\
$\begin{array}{l}\text { Kleibergen-Paap rk LM statistic, } p \text { value } \\
\quad \text { (under identification) }\end{array}$ & 0.000 \\
\hline
\end{tabular}

Dependent variable is $\Delta \mathrm{MP}_{i}$. Estimated with OLS. Country and sector dummies are included. SEs are robust against heteroscedasticity and shown in parentheses

$* p<0.10, * * p<0.05, * * * p<0.01$

identification (Angrist and Pischke 2009). High $F$ statistics are often found in large samples (e.g., Khandker et al. 2014).

\subsection{OLS results}

First, we estimate Eq. (3) using simple OLS. Table 4 shows that the impact of material productivity improvements on changes in competitiveness is positive and highly significant. The magnitude of the effect is modest, however. Having increased material productivity, a firm's market share-which is our measure for competitiveness-will increase by $3 \%$, on average.

\subsection{SLS results}

The results obtained when using 2 SLS are different. We find that average-scale material productivity improvements cause microeconomic competitiveness to increase by around $12 \%$. These results are highly significant, and the magnitude is more than four times larger compared to OLS. This illustrates that endogeneity biases the OLS estimate downwards, implying that firms that face the highest pressure on their market

Table 4 Second-stage results

\begin{tabular}{lll}
\hline & OLS & 2SLS \\
\hline$\Delta \mathrm{MP}_{i}$ & $\begin{array}{ll}0.0266^{* * *} \\
(0.0055)\end{array}$ & $\begin{array}{l}0.1172^{* * *} \\
(0.0273)\end{array}$ \\
Country dummies & YES & YES \\
Sector dummies & YES & YES \\
$R^{2}$ & 0.04 & 0.04 \\
$N$ & 52,772 & 52,772
\end{tabular}

Dependent variable is $\Delta \ln \left(\mathrm{COMP}_{i}\right)$. Estimated with OLS and 2SLS. Country and sector dummies are included. SEs are robust against heteroscedasticity and shown in parentheses

${ }^{*} p<0.10, * * p<0.05, * * * p<0.01$ 
shares are most likely to increase their material productivity. Hence, the dominant source of endogeneity appears to arise in the omitted variable bias from a market's dynamism and innovativeness, as typically spurred by competition, which put market shares under constant pressure but also correlate with (eco-)innovations. The low $R^{2}$ in both estimations does not undermine the validity of the estimates, especially as the regressors' variability is very limited due to their binary nature (e.g., Dell et al. 2012).

These results are in line with evidence brought forward in the literature in terms of finding a positive relationship between material productivity and competitiveness (Fh-ISI et al. 2005; Bleischwitz et al. 2009b; Schmidt and Schneider 2010; Ecorys 2011; Schröter et al. 2011; Bassi et al. 2012; AMEC and Bio IS 2013). However, this analysis considers the dynamic effects between firms, sectors, and countries as well as addresses the endogeneity of material productivity improvements.

\subsection{Sector and country heterogeneity}

Given the granular structure of the survey data, this subsection allows investigating whether there is any sector or country heterogeneity. To this end, sector and country specific effects are explicitly estimated by restricting the sample to the relevant dimensions. The results are shown in Tables 5 and $6 .^{12}$

\subsubsection{Sector heterogeneity}

There is considerable heterogeneity across sectors. The manufacturing sector, and in particular the manufacturing of wood, paper, paper products and printing as well as of basic metals, fabricated metal products, shows positive and significant effects of material productivity increases on market share growth. Furthermore, water supply, sewerage, waste management as well as wholesale and retail trade, and repair of motor vehicles indicate significant effects. These results suggest that the benefits from material productivity improvements are limited to certain material-intensive sectors, while the remaining sectors are not significantly affected; some even showing a negative (yet insignificant) sign. However, also financial and insurance activities increase their competitiveness, which could be due to increased material productivity in their IT systems (e.g., using Cloud services instead of large in-house servers). While the instrumentation remains robust for most sectors, the relatively low level of the Kleinbergen-Paap rk LM statistics could also explain the results for the financial and insurance sector.

\subsubsection{Country heterogeneity}

There is also considerable heterogeneity across countries. Firms in Estonia, Italy, Portugal, and Romania seem to be able to increase their competitiveness as a result

\footnotetext{
12 Explicitly estimating the country and sector specific effects serves as a starting point to analyse country and sector heterogeneity. More sophisticated techniques (e.g., random coefficient model, interacting material productivity with sectors within one specification) would require longer panels and sector specific instruments that allow explaining sufficient variation in the endogenous variable. For statistical reasons, this is not feasible in this analysis.
} 


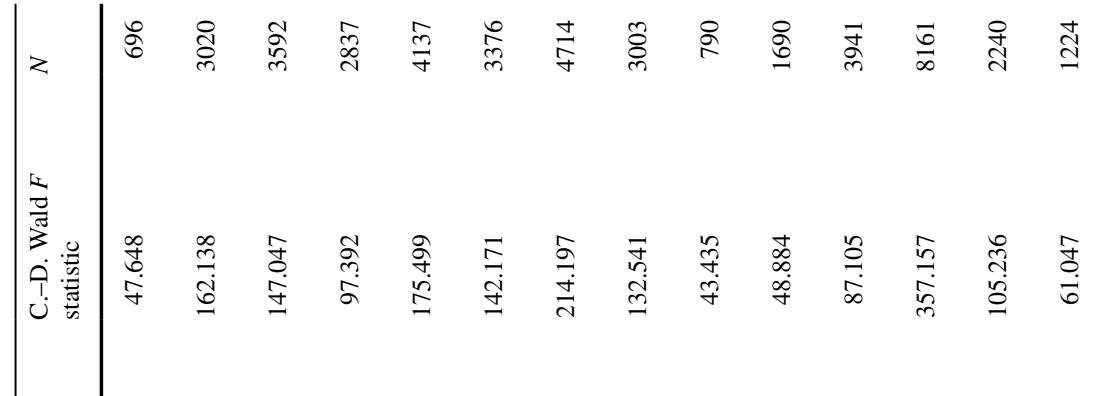

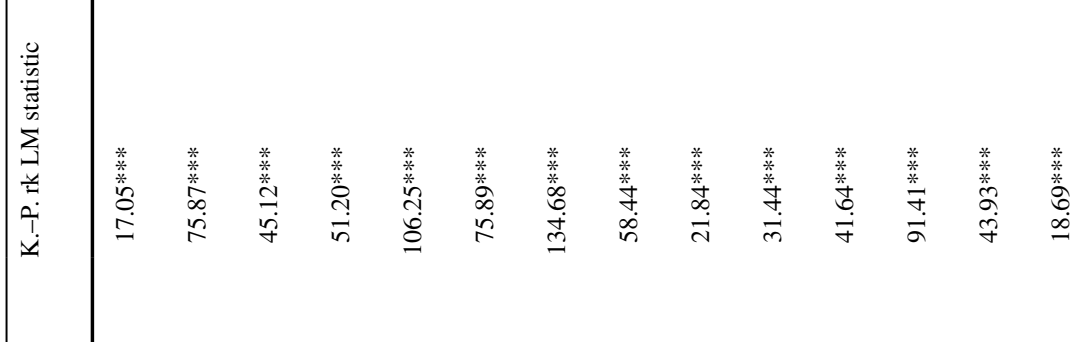

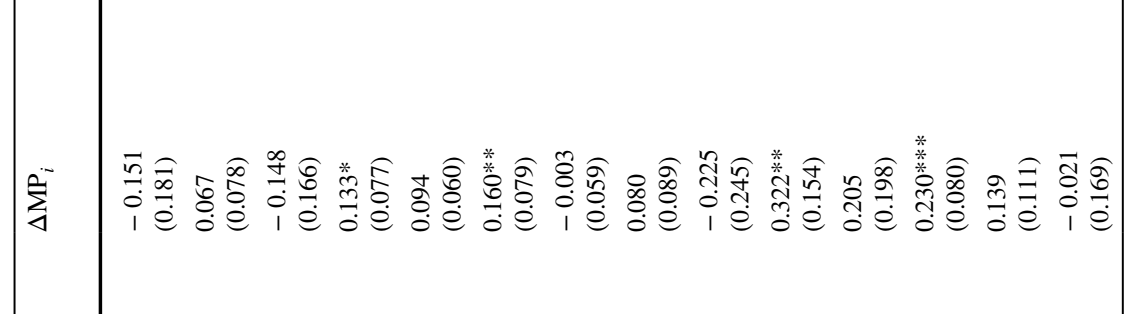

$$
\begin{aligned}
& 3
\end{aligned}
$$

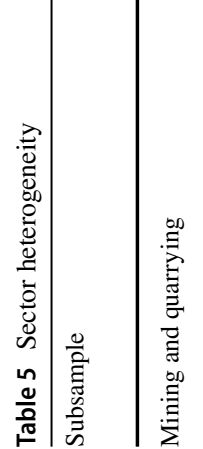

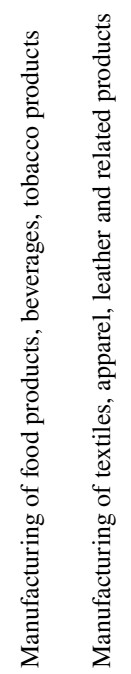

$$
\begin{aligned}
& \frac{2}{2}
\end{aligned}
$$

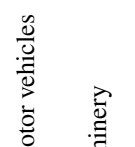

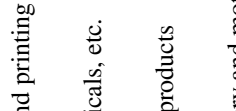

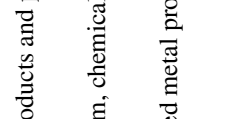

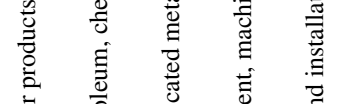

$$
\begin{aligned}
& \text { 苛 }
\end{aligned}
$$

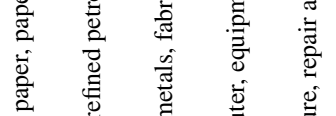

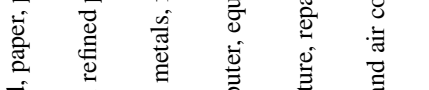

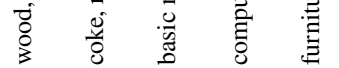

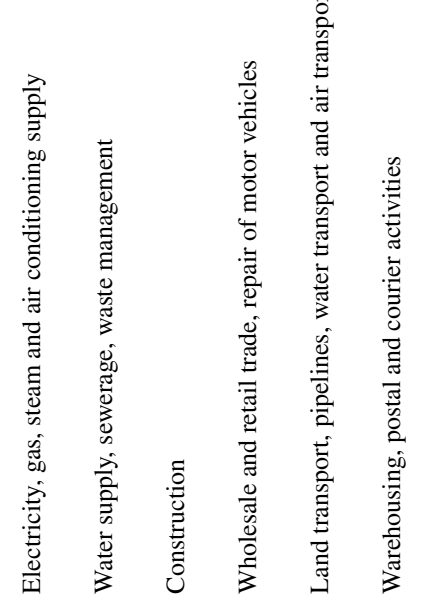

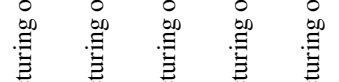

$$
\begin{aligned}
& \text { 章 }
\end{aligned}
$$




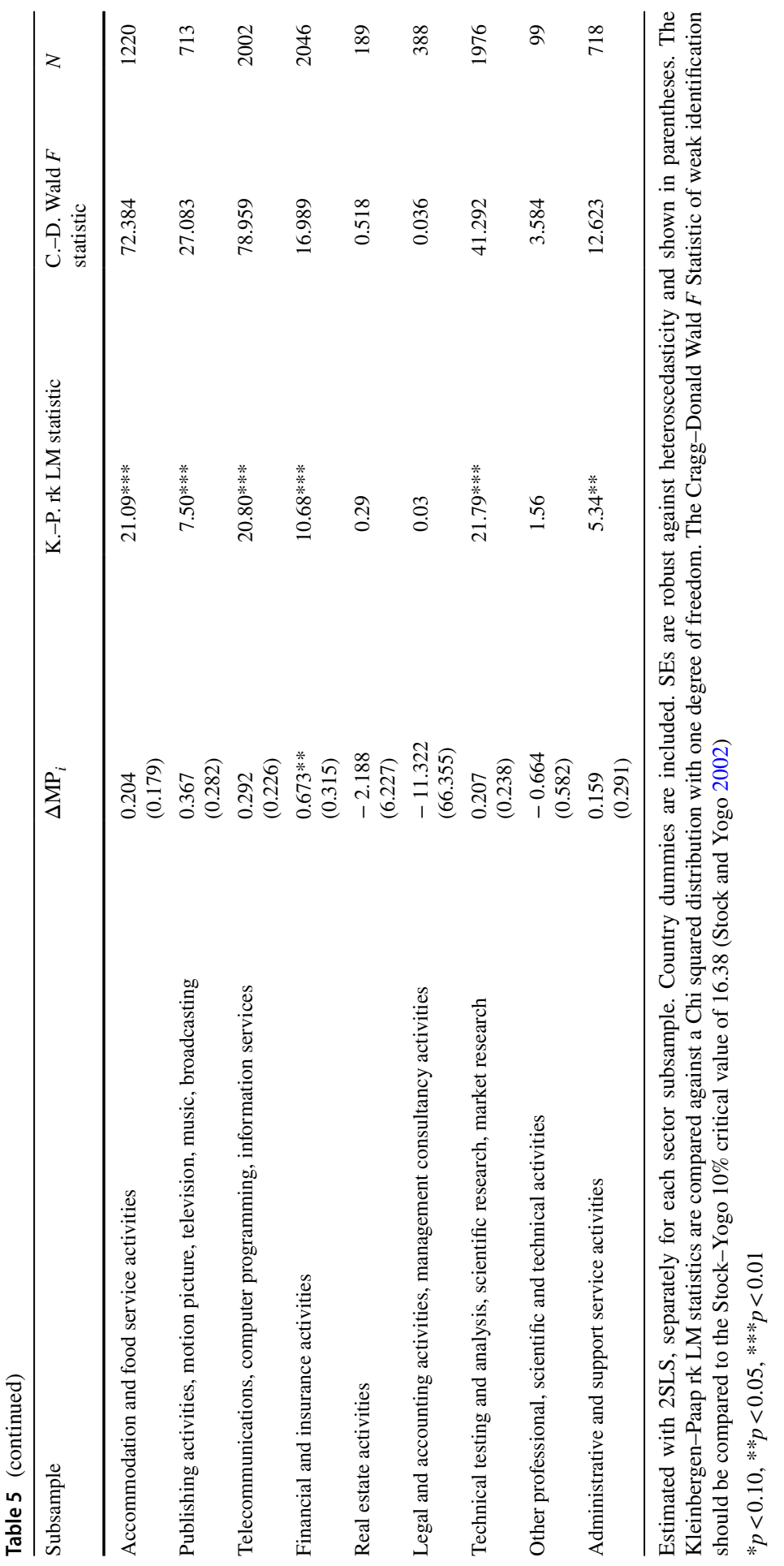


Table 6 Country heterogeneity

\begin{tabular}{|c|c|c|c|c|}
\hline Subsample & $\Delta \mathrm{MP}_{i}$ & K.-P. rk LM Statistic & $\begin{array}{l}\text { C.-D. Wald } F \\
\text { Statistic }\end{array}$ & $N$ \\
\hline Bulgaria & $\begin{array}{l}0.048 \\
(0.080)\end{array}$ & $64.84 * * *$ & 350.137 & 4583 \\
\hline Cyprus & $\begin{array}{l}0.198 \\
(0.158)\end{array}$ & $8.10 * * *$ & 58.347 & 1024 \\
\hline Czech Republic & $\begin{array}{l}-0.008 \\
(0.077)\end{array}$ & $118.85 * * *$ & 239.731 & 6357 \\
\hline Germany & $\begin{array}{l}0.029 \\
(0.128)\end{array}$ & $56.73 * * *$ & 70.973 & 4292 \\
\hline Estonia & $\begin{array}{l}0.401 * * \\
(0.173)\end{array}$ & $27.26 * * *$ & 80.853 & 1904 \\
\hline Hungary & $\begin{array}{l}0.212 \\
(0.148)\end{array}$ & $16.54 * * *$ & 20.130 & 1720 \\
\hline Italy & $\begin{array}{l}0.213 * * * \\
(0.063)\end{array}$ & $189.54 * * *$ & 430.822 & 14,921 \\
\hline Lithuania & $\begin{array}{l}0.013 \\
(0.110)\end{array}$ & $39.16^{* * *}$ & 117.905 & 1365 \\
\hline Latvia & $\begin{array}{l}-0.190 \\
(0.267)\end{array}$ & $10.47 * * *$ & 50.635 & 800 \\
\hline Portugal & $\begin{array}{l}0.096^{*} \\
(0.053)\end{array}$ & $121.33 * * *$ & 235.601 & 6114 \\
\hline Romania & $\begin{array}{l}0.096 * \\
(0.054)\end{array}$ & $253.58 * * *$ & 981.726 & 8765 \\
\hline Slovakia & $\begin{array}{l}0.119 \\
(0.292)\end{array}$ & $6.60 * *$ & 9.889 & 927 \\
\hline
\end{tabular}

Estimated with 2SLS, separately for each country subsample. Sector dummies included. SEs are robust against heteroscedasticity and shown in parentheses. The Kleinbergen-Paap rk LM statistics for under identification are compared against a Chi squared distribution with one degree of freedom. Cragg-Donald Wald $F$ statistics of weak identification to be compared to the Stock-Yogo $10 \%$ critical value 16.38 (Stock and Yogo 2002)

$* p<0.10, * * p<0.05, * * * p<0.01$

of material productivity increases, while the other countries do not significantly improve or reduce their competitiveness. A more detailed analysis on the factors underlying these results goes beyond the scope of this paper, but any future analysis could investigate whether there are decreasing marginal benefits from material productivity increases.

Overall, the analysis on sector and country heterogeneity indicates that the positive effect of material productivity increases on competitiveness is associated with certain material-intensive sectors and countries. This suggests that not all sectors and countries are likely to benefit from incentivising firms to realise eco-innovations that lead to a material productivity increase-a crucial policy insight. 
Table 7 Control variables

\begin{tabular}{|c|c|c|c|c|}
\hline & (1) & (2) & (3) & (4) \\
\hline$\Delta \mathrm{MP}_{i, 2008}$ & $\begin{array}{l}0.1172 \text { *** } \\
(0.0273)\end{array}$ & $\begin{array}{l}0.1240 * * * \\
(0.0261)\end{array}$ & $\begin{array}{l}0.1011^{* *} \\
(0.0477)\end{array}$ & $\begin{array}{l}0.1078 * * \\
(0.0480)\end{array}$ \\
\hline$\Delta$ size $_{i, 2008}$ & & $\begin{array}{l}0.4216 * * * \\
(0.0116)\end{array}$ & $\begin{array}{l}0.4208 * * * \\
(0.0116)\end{array}$ & $\begin{array}{l}0.4211 * * * \\
(0.0116)\end{array}$ \\
\hline$\Delta$ product $_{i, 2008}$ & & & $\begin{array}{l}0.0097 \\
(0.0077)\end{array}$ & $\begin{array}{l}0.0087 \\
(0.0077)\end{array}$ \\
\hline$\Delta$ process $_{i, 2008}$ & & & $\begin{array}{l}0.0095 \\
(0.0068)\end{array}$ & $\begin{array}{l}0.0089 \\
(0.0068)\end{array}$ \\
\hline$\Delta$ organisational $_{i, 2008}$ & & & $\begin{array}{l}-0.0025 \\
(0.0072)\end{array}$ & $\begin{array}{l}-0.0035 \\
(0.0072)\end{array}$ \\
\hline$\Delta$ marketing $_{i, 2008}$ & & & $\begin{array}{l}0.0059 \\
(0.0078)\end{array}$ & $\begin{array}{l}0.0047 \\
(0.0078)\end{array}$ \\
\hline national $_{i}$ & & & & $\begin{array}{l}0.0061 \\
(0.0050)\end{array}$ \\
\hline europe $_{i}$ & & & & $\begin{array}{l}0.0025 \\
(0.0083)\end{array}$ \\
\hline $\mathrm{RoW}_{i}$ & & & & $\begin{array}{l}0.0062 \\
(0.0145)\end{array}$ \\
\hline Country dummies & YES & YES & YES & YES \\
\hline Sector dummies & YES & YES & YES & YES \\
\hline$R^{2}$ & 0.04 & 0.10 & 0.10 & 0.10 \\
\hline$N$ & 52,772 & 52,677 & 52,677 & 52,557 \\
\hline
\end{tabular}

Dependent variable is $\Delta \ln \left(\mathrm{COMP}_{i}\right)$. Estimated with 2SLS. Country and sector dummies are included. SEs are robust against heteroscedasticity heterogeneity and shown in parentheses ${ }^{*} p<0.10,{ }^{* *} p<0.05, * * * p<0.01$

\subsection{Robustness tests}

Throughout all robustness checks, our instrumentation strategy remains robust. The country specific effects are jointly significant and thus included in all estimations. The same holds true for the sector specific effects. We excluded individual countries and sectors to identify specific subsample that may drive results, but those results are not substantially different to the ones in Table 4. Furthermore, we changed the assumptions on our standard errors to homoscedastic, clustered over countries, sectors, and both. Our estimations are robust to all such changes.

Table 7 gradually introduces further control variables that the literature identifies as being determinants of competitiveness. In terms of the underlying structural model of Eq. (2), controls comprise both additional time trends and level variables. The table shows that the 'raw effect' is robust against introducing further control variables.

Column 1 shows the baseline model for reference. Column 2 investigates whether the level of employment affects the competitive stance (Hall 1987; Yasuda 2005). 
Table 8 Restricted samples

\begin{tabular}{llll}
\hline & SMEs only & Excl. financial sectors & Manufacturing only \\
\hline$\Delta \mathrm{MP}_{i}$ & $0.1469^{* * *}$ & $0.1095^{* * *}$ & $0.0594^{* *}$ \\
& $(0.0330)$ & $(0.0277)$ & $(0.0303)$ \\
Country dummies & YES & YES & YES \\
Sector dummies & YES & YES & YES \\
$R^{2}$ & 0.04 & 0.04 & 0.03 \\
$N$ & 46,919 & 51,082 & 24,679 \\
\hline
\end{tabular}

Dependent variable is $\Delta \ln \left(\mathrm{COMP}_{i}\right)$. Estimated with 2SLS. Country and sector dummies are included. SE are robust against heteroscedasticity and shown in parentheses

${ }^{*} p<0.10, * * p<0.05, * * * p<0.01$

Adhering to first differences, we introduce the change in employment. There is a large and positive effect of increasing the size of the firm and competitiveness. ${ }^{13}$

Column 3 controls for all other innovations affecting productivity and competitiveness, i.e., product, process, organisational, or marketing, to isolate the effect of changes in material productivity on competitiveness. This is likely to control for another important source of potential endogeneity. Material productivity may grow along with-or as a by-product of-improvements in labour or capital productivity resulting from those innovations. By controlling for those effects, we isolate the impact material productivity increases have on market share growth.

More specifically, different innovation types either change (1) the current product line-up; (2) the level of process structures and efficiency; (3) management structures and efficiency; or (4) marketing capacities, which altogether shape a firm's contemporary level of competitiveness. In turn, an innovation is defined in the CIS as the market introduction of a new or significantly improvement in one of the four innovation categories. Since this entails some form of change occurring, these variables can be included in our main model (Eq. 3). Product, process, and organisational innovations are positively but insignificantly associated with competitiveness.

Column 4 additionally controls for differential time trends concerning the regional scope of a firm's sales. This entails the notion that firms supplying foreign markets are more competitive compared to those supplying local markets (Baldwin and Robert-Nicoud 2008). The survey asks in which market the firm generated most turnovers, local/regional (39.6\% of the sample firms), national (45.6\% of the sample firms), Europe (12.2\% of the sample firms), or the rest of the world $(2.7 \%$ of the sample firms). However, estimates are inconclusive in our case.

Table 8 displays further robustness checks by restricting the sample of firms considered. First, we restrict our sample to SMEs, thus reducing our sample by $11 \%$. According to the definition of the EU, firms are considered to fall into this category

\footnotetext{
13 Please note that due to data protection clauses, the CIS 2006-2008 does not report the actual number of employees but rather three categories. The first one is between 10 and 49 employees (55.9\% of all sample firms), the second between 50 and 249 (34.5\% of all sample firms), and the third are firms above 250 employees $\left(9.6 \%\right.$ of all sample firms). $\Delta$ size $_{i, 2008}$ thus measures the change in category, ranging from -2 to +2 .
} 
Table 9 Distribution of the standard errors for the coefficient of interest from 500 placebo 2SLS regressions

\begin{tabular}{llllllllll}
\hline & $\min$ & $1 \%$ & $5 \%$ & $25 \%$ & $50 \%$ & $75 \%$ & $95 \%$ & $99 \%$ & $\max$ \\
\hline $\operatorname{se}(\gamma)_{\text {placebo }}$ & 0.469 & 0.577 & 0.785 & 1.478 & 3.111 & 11.98 & 324.73 & 4010 & $3,462,073$ \\
\hline
\end{tabular}

if they have below 250 employees and an annual turnover of below or equal to EUR 50 million (EC 2015c). In addition, we restrict our sample to the so-called nonfinancial business economy, defined as the NACE sectors B-J and L-N (EC 2013). Finally, we only consider manufacturing firms (NACE code C). Across all subsamples, the effect remains positive and significant.

Finally, we implement a placebo strategy to test the instrument's strength as proposed by Bound et al. (1995). Specifically, we generate 500 binomial random variables with a success probability equal to the mean of our binary instrument. This creates independent vectors that by construction exhibit the same statistical properties as our instrument. As we repeat the 2SLS procedure with every generated instrument, we would expect the precision of placebo results to be lower compared to those estimations presented previously. Otherwise, suspicion of finite sample bias would undermine confidence in our results.

As expected, the placebo results' standard errors lay far apart from those presented in Table 4. Table 9 presents the distribution of the placebo standard errors. Evidently, the precision our previous estimates (0.0267) exceeds even the most precise placebo results by an order of magnitude. This suggests that our instrument passes the non-robustness test proposed by Bound et al. (1995).

\subsection{The effect of material productivity improvements on environmental performance}

Given that eco-innovations, including those leading to material productivity improvements, are thought to address both economic and environmental concerns (Machiba 2010; Kemp et al. 2013), we complement our main analysis by estimating the relationship between material productivity improvements and the $\mathrm{CO}_{2}$ footprint of firms. The CIS 2006-2008 includes binary information on whether or not firms have reduced their $\mathrm{CO}_{2}$ footprint. Hence, a positive relationship would indicate that improving material productivity reduces the $\mathrm{CO}_{2}$ footprint. Since changes in material productivity can be interpreted as an input-output relationship and the carbon footprint as a result of this relationship, it is reasonable to assume that material productivity is exogenous in our model and timeframe. We thus estimate the following model:

$$
\begin{aligned}
\Delta \mathrm{CFP}_{t, i}= & \alpha_{0}+\alpha_{1} \Delta M P_{t, i}+\alpha_{2} \Delta M P_{t, i} \times \text { product }_{i}+\alpha_{3} \Delta M P_{t, i} \times \text { process }_{i} \\
& +\alpha_{4} \Delta \mathrm{MP}_{t, i} \times \text { organisational }_{i}+\alpha_{5} \Delta M P_{t, i} \times \text { marketing }_{i}+\alpha_{6} \text { product }_{i}+\alpha_{7} \text { process }_{i} \\
& +\alpha_{8} \text { organisational }_{\mathrm{i}}+\alpha_{9} \text { marketing }_{i}+\Delta \mathbf{x}_{\mathrm{t}, \mathrm{i}} \boldsymbol{\beta}+\mu_{s}+\lambda_{c}+\varepsilon_{t, i},
\end{aligned}
$$


Table 10 Effect of material productivity increases on the $\mathrm{CO}_{2}$ footprint

\begin{tabular}{lll}
\hline & Marginal effect at the mean & Average marginal effect \\
\hline$\Delta \mathrm{MP}_{i}$ & $0.3133^{* * *}$ & $0.2924 * * *$ \\
& $(0.0091)$ & $(0.0082)$ \\
Full set of controls & YES & YES \\
Country dummies & YES & YES \\
Sector dummies & YES & YES \\
Pseudo- $R^{2}$ & 0.30 & 0.30 \\
$N$ & 54,234 & 54,234 \\
\hline
\end{tabular}

Dependent variable is $\Delta \mathrm{CFP}_{i}$. Estimated with probit. Country and sector dummies are included. SE are robust against heteroscedasticity and shown in parentheses

${ }^{*} p<0.10, * * p<0.05, * * * p<0.01$

where $\mathrm{CFP}_{t, i}$ is the $\mathrm{CO}_{2}$ footprint, $\mathrm{MP}_{i}$ is material productivity, product $_{i}$, process $_{i}$, organisational ${ }_{i}$ and marketing ${ }_{i}$ are dummies to account for innovation types, $\mathbf{x}_{\mathrm{t}, \mathrm{i}}$ denotes a vector of control variables ( $\Delta$ size, turnover growth, environmental programme (binary) and export activity as measured by national, europe, RoW), $\mu_{s}$ are sector specific effects, $\lambda_{c}$ represents country specific effects, and $\varepsilon_{t, i}$ is the error term.

We interact material productivity increases with all types of innovations to better isolate the 'pure effect' of material productivity improvements on the $\mathrm{CO}_{2}$ footprint on firms, disentangling the effects of the different types of innovations (i.e., non-material productivity innovations) on the $\mathrm{CO}_{2}$ footprint. The model is estimated applying a probit approach. The results of the probit estimations can be found in Table 14 in "Appendix".

Table 10 shows the marginal effect at the mean and the average marginal effect of material productivity improvements on reductions in the $\mathrm{CO}_{2}$ footprint, using the results from Column 4 in Table 14 in "Appendix", i.e., including all control variables. The probability of reducing the $\mathrm{CO}_{2}$ footprint for the average firm increases by around $31 \%$ as a result of an increase in material productivity compared to not increasing material productivity. Similarly, the average effect of enhancing material productivity on the probability across all firms of reducing the $\mathrm{CO}_{2}$ footprint amounts to $29 \%$. Both are highly significant and relevant effects. We thus provide evidence that material productivity improvements lead to a reduction of the $\mathrm{CO}_{2}$ footprint of firms.

\section{Discussion}

Our results provide evidence for a positive and causal impact of material productivity improvements on microeconomic competitiveness, limited to some material-intensive sectors and certain European countries. By considering over 52,000 firms across 23 sectors and $12 \mathrm{EU}$ countries, we take dynamic effects and heterogeneity across firms, sectors, and countries into account. Furthermore, this is to our 
knowledge the first study that investigates this effect based on such wide-ranging data. Previous studies have failed to address the problem of endogeneity, which we show to be a relevant problem. Furthermore, we provide evidence that increases in material productivity also improve the firm's environmental performance. We thus conclude that increasing material productivity can reconcile competitiveness and climate change mitigation objectives for certain firms, sectors, and countries.

Nevertheless, our analysis faces some limitations. By reviewing the literature, we grouped potential links between material productivity and competitiveness into channels. Given the limited information available in the CIS 2006-2008, we were unable to identify which of such channels drives our results. In addition, our endogenous variable is binary, i.e., we cannot provide any information on the magnitude and underlying factors (types of innovations and materials) of the observed material productivity improvements that cause firm's increases in competitiveness. Both limitations are due to the way that the CIS survey has been constructed. Given the very limited data sources academics and policymakers can rely on for investigating the effects of changes in material productivity, the CIS 2006-2008 is arguably the most comprehensive data set available. However, any future study would greatly benefit if the CIS would (1) consistently survey firms in all EU countries and sectors about their material productivity improvements in every wave; (2) collect information in the form of continuous and material as well as innovation specific variables; and (3) introduce questions that can be used as instruments (e.g., any natural experiment type of information).

Our results contain one crucial policy insight—enable eco-innovations that result in material productivity improvements through public financial support, especially in certain material-intensive sectors and countries. As we show that eco-innovations triggered by public financial support leading to improvements in material productivity increase the competitive stance of firms as well as reduce their $\mathrm{CO}_{2}$ footprint across firms, sectors, and countries within the EU, the EU and its member states are encouraged to support the development and diffusion of such eco-innovations. This can be achieved by providing sufficient finance to firms through, for instance, targeted investment programmes and reducing investment barriers (Jordan et al. 2014; Flachenecker and Rentschler 2015; Shahbazi et al. 2015; Ghisetti et al. 2016). Mainstreaming such efforts across current investment programmes, in particular, the European Fund for Strategic Investments (EC 2014c) and the Circular Economy Package (EC 2015a), would be consistent with our findings. Furthermore, the benefits of policy-guided change have been discussed in depth in the literature (Porter 1990). Hence, enabling eco-innovations does not only trigger direct benefits, but is also likely to result in co-benefits, such as reducing potential rebound effects (Font Vivanco et al. 2016), creating new business models (Machiba 2010), and enabling systematic change towards more sustainable economies (Bleischwitz et al. 2009a; Kemp et al. 2013), among others.

Deadweight effects are an important concern for public measures that try to incentivise innovations through financial support. To approximate this risk, we estimated the sample proportions of so-called always-takers, compliers, and nevertakers, following standard practices used in the LATE literature (Angrist and Pischke 2009). Compliers are firms that innovate because of the availability of public 
support. Never-takers will not innovate regardless of the availability of public funds. Always-takers are firms that receive public financial support but would have realised an eco-innovation anyway, thus generating deadweight effects. In our sample, 15\% of firms are always-takers, pointing at a considerable but limited risk of deadweight effects. This provides evidence that the principle of additionality in public funding needs to be respected to keep such adverse effects to a minimum.

\section{Conclusions}

The aim of our paper is to investigate the claim that material productivity improvements positively affect microeconomic competitiveness. This assertion is broad forward by scholars and policymakers, in particular in the European Union (EU), but the underlying evidence base is restricted to individual firms, sectors, or countries, and the empirical investigations do not adequately address the endogeneity of changes in material productivity. After reviewing the literature on the channels linking material productivity and competitiveness on the firm level, we address both gaps by analysing data from the Community Innovation Survey 2006-2008 comprising over 52,000 firms across 23 sectors and $12 \mathrm{EU}$ member states.

Using a two-stage least square instrumental variable approach, we provide evidence for a positive and causal impact of material productivity improvements on microeconomic competitiveness. We use the availability of public financial support to instrument changes in material productivity. Interpreting our results in the spirit of the local average treatment effect theorem, our findings provide evidence for those firms that received public financial support and had an eco-innovation. This effect is heterogeneous across sectors and countries, suggesting that certain material-intensive sectors and countries benefit from material productivity increases, while others show no significantly positive or negative effects. We further show that material productivity improvements also reduce the carbon dioxide $\left(\mathrm{CO}_{2}\right)$ footprint of firms. Thus, we show that certain firms, sectors, and countries can improve their competitiveness and decrease their $\mathrm{CO}_{2}$ footprint simultaneously-economic and environmental objectives can be consolidated.

Since material productivity improvements in our sample depend on realising an eco-innovation through public financial support, our results call on policymakers in the EU to focus their efforts on enabling eco-innovation through providing sufficient and adequate finance as well as reducing investment barriers for firms. Future research on the issue would need to benefit from more precise information on the magnitudes of material productivity improvements that are required to achieve both economic and environmental objectives as well as a deeper understanding of those firms, sectors, regions, and countries that are likely to 'win' and 'lose' from material productivity improvements. This would be an important step forward in addressing potentially adverse effects of the transition towards more material productive economies.

Acknowledgements The authors would like to thank Raimund Bleischwitz, Paolo Agnolucci, Jun Rentschler, Paul Ekins, Valentina Schaumburger, Toshi H. Arimura, and three anonymous reviewers for useful 
comments and suggestions. The participants of the Annual Conference of the European Association of Environmental and Resource Economists in July 2017 in Athens and of the Use Less Seminar organised by the University of Cambridge in January 2017 in Cambridge provided helpful comments. Additionally, the authors are thankful to the European Commission's Directorate-General Eurostat for providing the data of the Community Innovation Survey (research project proposal number 259/2014-CIS). The results and conclusions are those of the authors and do not necessarily represent the official position of the European Commission, its member states, or any organisation the authors are associated with.

Open Access This article is distributed under the terms of the Creative Commons Attribution 4.0 International License (http://creativecommons.org/licenses/by/4.0/), which permits unrestricted use, distribution, and reproduction in any medium, provided you give appropriate credit to the original author(s) and the source, provide a link to the Creative Commons license, and indicate if changes were made.

\section{Appendix}

See Tables 11, 12, 13, and 14 and Fig. 1.

Table 11 Countries of the sample

\begin{tabular}{lcc}
\hline 12 countries & Frequency & Percentage \\
\hline Bulgaria & 4583 & 8.69 \\
Cyprus & 1024 & 1.94 \\
Czech Republic & 6357 & 12.04 \\
Germany & 4292 & 8.11 \\
Estonia & 1904 & 3.61 \\
Hungary & 1720 & 3.26 \\
Italy & 14,921 & 28.29 \\
Lithuania & 1365 & 2.59 \\
Latvia & 800 & 1.52 \\
Portugal & 6114 & 11.59 \\
Romania & 8765 & 16.59 \\
Slovakia & 927 & 1.76 \\
Total & 52,772 & 100.00 \\
\hline
\end{tabular}




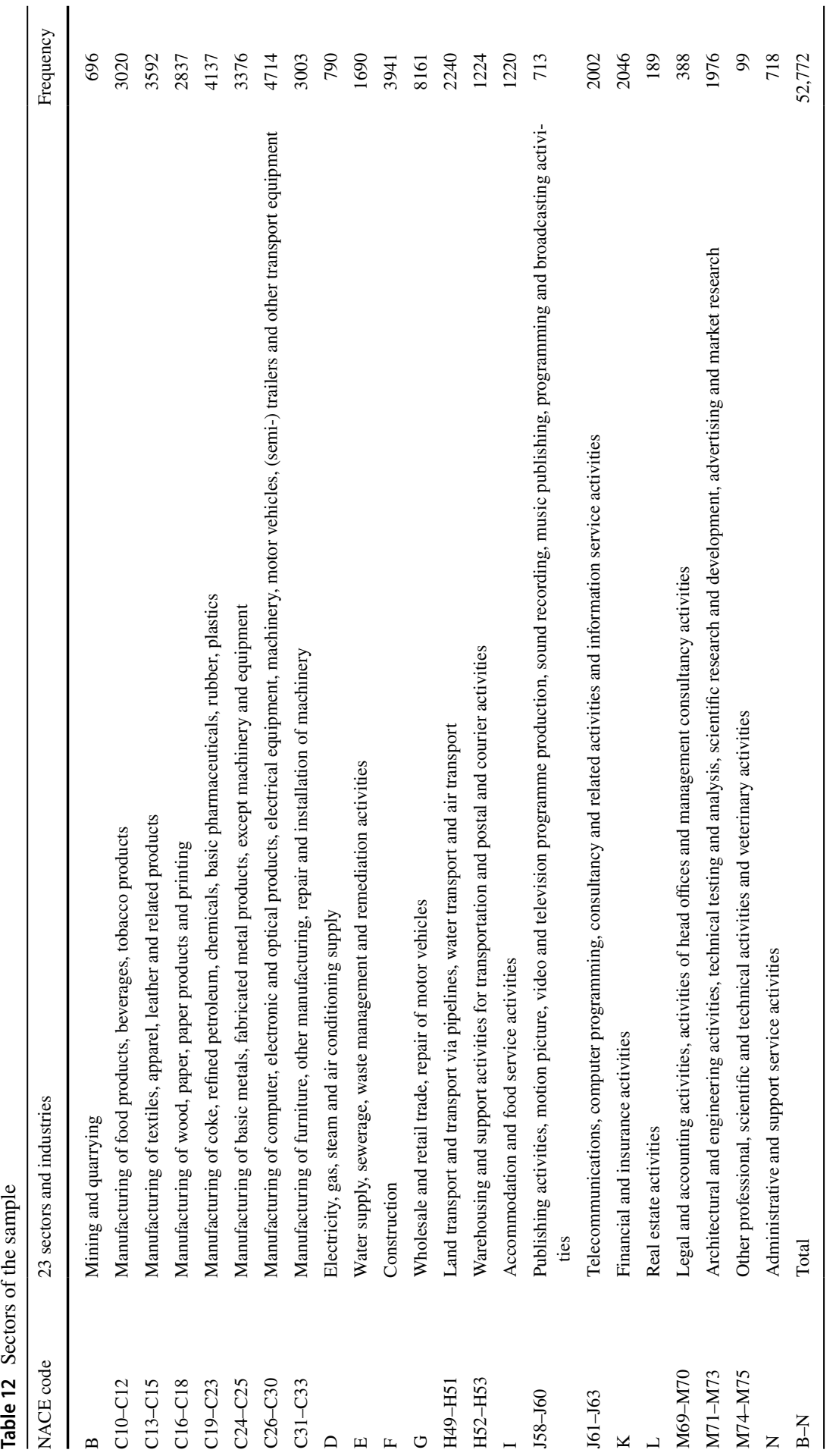


Table 13 Instrument properties

Dependent: public financial support $(P F S)$

\begin{tabular}{|c|c|}
\hline Constant & $\begin{array}{l}0.013 \\
(0.010)\end{array}$ \\
\hline \multicolumn{2}{|l|}{ Country } \\
\hline Bulgaria & Reference \\
\hline Cyprus & $\begin{array}{l}0.002 \\
(0.005)\end{array}$ \\
\hline Czech Republic & $\begin{array}{l}0.039 * * * \\
(0.004)\end{array}$ \\
\hline Germany & $\begin{array}{l}0.024 * * * \\
(0.005)\end{array}$ \\
\hline Estonia & $\begin{array}{l}0.013 * * \\
(0.005)\end{array}$ \\
\hline Hungary & $\begin{array}{l}0.003 \\
(0.006)\end{array}$ \\
\hline Italy & $\begin{array}{l}0.094 * * * \\
(0.004)\end{array}$ \\
\hline Lithuania & $\begin{array}{l}0.019 * * * \\
(0.007)\end{array}$ \\
\hline Latvia & $\begin{array}{l}0.008 \\
(0.007)\end{array}$ \\
\hline Portugal & $\begin{array}{l}0.024 * * * \\
(0.004)\end{array}$ \\
\hline Romania & $(0.003)$ \\
\hline Slovakia & $\begin{array}{l}0.036 * * * \\
(0.009)\end{array}$ \\
\hline \multicolumn{2}{|l|}{ Sector } \\
\hline B & Reference \\
\hline $\mathrm{C} 10-\mathrm{C} 12$ & $\begin{array}{l}0.003 \\
(0.011)\end{array}$ \\
\hline C13-C15 & $\begin{array}{l}-0.035^{* * * *} \\
(0.010)\end{array}$ \\
\hline $\mathrm{C} 16-\mathrm{C} 18$ & $\begin{array}{l}-0.002 \\
(0.011)\end{array}$ \\
\hline $\mathrm{C} 19-\mathrm{C} 23$ & $\begin{array}{l}0.007 \\
(0.010)\end{array}$ \\
\hline $\mathrm{C} 24-\mathrm{C} 25$ & $\begin{array}{l}0.003 \\
(0.010)\end{array}$ \\
\hline $\mathrm{C} 26-\mathrm{C} 30$ & $\begin{array}{l}-0.002 \\
(0.010)\end{array}$ \\
\hline C31-C33 & $\begin{array}{l}-0.007 \\
(0.010)\end{array}$ \\
\hline $\mathrm{D}$ & $\begin{array}{l}0.051 * * * \\
(0.015)\end{array}$ \\
\hline $\mathrm{E}$ & $\begin{array}{l}0.079 * * * \\
(0.013)\end{array}$ \\
\hline $\mathrm{F}$ & $\begin{array}{l}0.024 * * \\
(0.011)\end{array}$ \\
\hline
\end{tabular}


Table 13 (continued)

Dependent: public financial support $(P F S)$

\begin{tabular}{ll}
\hline G & $-0.025 * *$ \\
& $(0.010)$ \\
H49-H51 & $0.030 * * *$ \\
& $(0.011)$ \\
H52-H53 & -0.019 \\
& $(0.012)$ \\
I & $-0.024 *$ \\
& $(0.013)$ \\
J58-J60 & $-0.038 * * *$ \\
& $(0.011)$ \\
J61-J63 & $-0.033 * * *$ \\
& $(0.010)$ \\
K & $-0.023 * *$ \\
& $(0.011)$ \\
L & -0.024 \\
& $(0.021)$ \\
M69-M70 & $-0.037 * * *$ \\
& $(0.012)$ \\
M71-M73 & 0.009 \\
M74-M75 & $(0.011)$ \\
& -0.013 \\
& $(0.022)$ \\
N & $-0.040 * * *$ \\
& $(0.012)$ \\
&
\end{tabular}

\section{Largest market}

Locally

Nationally

Reference

$0.010 * * *$

(0.003)

Europe

$-0.003$

(0.004)

Outside Europe

0.007

(0.007)

\section{Employment, 2006}

$<50$ employees

Reference

50-250 employees

$0.011 * * *$

(0.004)

$>250$ employees

$0.036^{* * *}$

(0.009)

\section{Employment, 2008}

$<50$ employees

Reference

50-250 employees

$0.018 * * *$

(0.004)

$>250$ employees

$0.023 * * *$

(0.009)

Turnover (in billions), 2006

0.007

(0.037)

Turnover (in billions), 2008 
Table 13 (continued)

\begin{tabular}{ll}
\hline Dependent: public financial support $(P F S)$ & \\
\hline$R^{2}$ & 0.03 \\
$N$ & 52,531
\end{tabular}

Estimated by OLS. Heteroscedasticity robust standard errors in parenthesis

$* p<0.10, * * p<0.05, * * * p<0.01$

Table 14 Probit estimations

\begin{tabular}{|c|c|c|c|c|}
\hline & (1) & (2) & (3) & (4) \\
\hline$\Delta \mathrm{MP}_{i}$ & $\begin{array}{l}1.4687 * * * \\
(0.0167)\end{array}$ & $\begin{array}{l}1.5483 * * * \\
(0.0396)\end{array}$ & $\begin{array}{l}1.4687 * * * \\
(0.0419)\end{array}$ & $\begin{array}{l}1.4683 * * * \\
(0.0420)\end{array}$ \\
\hline$\Delta$ product $_{i}$ & & $\begin{array}{l}0.1943 * * * \\
(0.0241)\end{array}$ & $\begin{array}{l}0.1564 * * * \\
(0.0252)\end{array}$ & $\begin{array}{l}0.1616^{* * * *} \\
(0.0253)\end{array}$ \\
\hline$\Delta \mathrm{MP}_{i} \times \Delta$ product $_{i}$ & & $\begin{array}{l}-0.1712 * * * \\
(0.0377)\end{array}$ & $\begin{array}{l}-0.1678 * * * \\
(0.0398)\end{array}$ & $\begin{array}{l}-0.1689 * * * \\
(0.0399)\end{array}$ \\
\hline$\Delta$ process $_{i}$ & & $\begin{array}{l}0.3663 * * * \\
(0.0233)\end{array}$ & $\begin{array}{l}0.3019 * * * \\
(0.0246)\end{array}$ & $\begin{array}{l}0.3011 * * * \\
(0.0246)\end{array}$ \\
\hline$\Delta \mathrm{MP}_{i} \times \Delta$ process $_{i}$ & & $\begin{array}{l}-0.2478 * * * \\
(0.0389)\end{array}$ & $\begin{array}{l}-0.2449 * * * \\
(0.0411)\end{array}$ & $\begin{array}{l}-0.2432 * * * \\
(0.0412)\end{array}$ \\
\hline$\Delta$ organisational $_{i}$ & & $\begin{array}{l}0.3571 * * * \\
(0.0223)\end{array}$ & $\begin{array}{l}0.2904 * * * \\
(0.0234)\end{array}$ & $\begin{array}{l}0.2921 \text { *** } \\
(0.0234)\end{array}$ \\
\hline$\Delta \mathrm{MP}_{i} \times \Delta$ organisational $_{i}$ & & $\begin{array}{l}-0.1179 * * * \\
(0.0380)\end{array}$ & $\begin{array}{l}-0.1348^{* * * *} \\
(0.0400)\end{array}$ & $\begin{array}{l}-0.1351 * * * \\
(0.0400)\end{array}$ \\
\hline$\Delta$ marketing $_{i}$ & & $\begin{array}{l}0.1944 * * * \\
(0.0227)\end{array}$ & $\begin{array}{l}0.1890 * * * \\
(0.0237)\end{array}$ & $\begin{array}{l}0.1881 * * * \\
(0.0238)\end{array}$ \\
\hline$\Delta \mathrm{MP}_{i} \times \Delta$ marketing $_{i}$ & & $\begin{array}{l}-0.0962 * * * \\
(0.0362)\end{array}$ & $\begin{array}{l}-0.0668^{*} \\
(0.0381)\end{array}$ & $\begin{array}{l}-0.0684 * \\
(0.0382)\end{array}$ \\
\hline environmental programme $_{i}$ & & & $\begin{array}{l}0.5173 * * * \\
(0.0179)\end{array}$ & $\begin{array}{l}0.5197 * * * \\
(0.0179)\end{array}$ \\
\hline turnover $_{i, 2008} /$ turnover $_{i, 2006}$ & & & $\begin{array}{l}0.0000 \\
(0.0093)\end{array}$ & $\begin{array}{l}0.0002 \\
(0.0093)\end{array}$ \\
\hline$\Delta$ size $_{i}$ & & & $\begin{array}{l}0.0195 \\
(0.0294)\end{array}$ & $\begin{array}{l}0.0245 \\
(0.0296)\end{array}$ \\
\hline national $_{i}$ & & & & $\begin{array}{l}-0.0426^{* * *} \\
(0.0191)\end{array}$ \\
\hline europe $_{i}$ & & & & $\begin{array}{l}-0.0988 * * * \\
(0.0295)\end{array}$ \\
\hline $\operatorname{RoW}_{i}$ & & & & $\begin{array}{l}-0.0898 * * \\
(0.0488)\end{array}$ \\
\hline Country dummies & YES & YES & YES & YES \\
\hline Sector dummies & YES & YES & YES & YES \\
\hline Pseudo- $R^{2}$ & 0.24 & 0.28 & 0.30 & 0.29 \\
\hline$N$ & 58,478 & 58,478 & 54,401 & 54,234 \\
\hline
\end{tabular}

Dependent variable is $\Delta \mathrm{CFP}_{i}$. Estimated with probit. Country and sector dummies are included. SEs are robust against heteroscedasticity and shown in parentheses

$* p<0.10, * * p<0.05, * * * p<0.01$ 


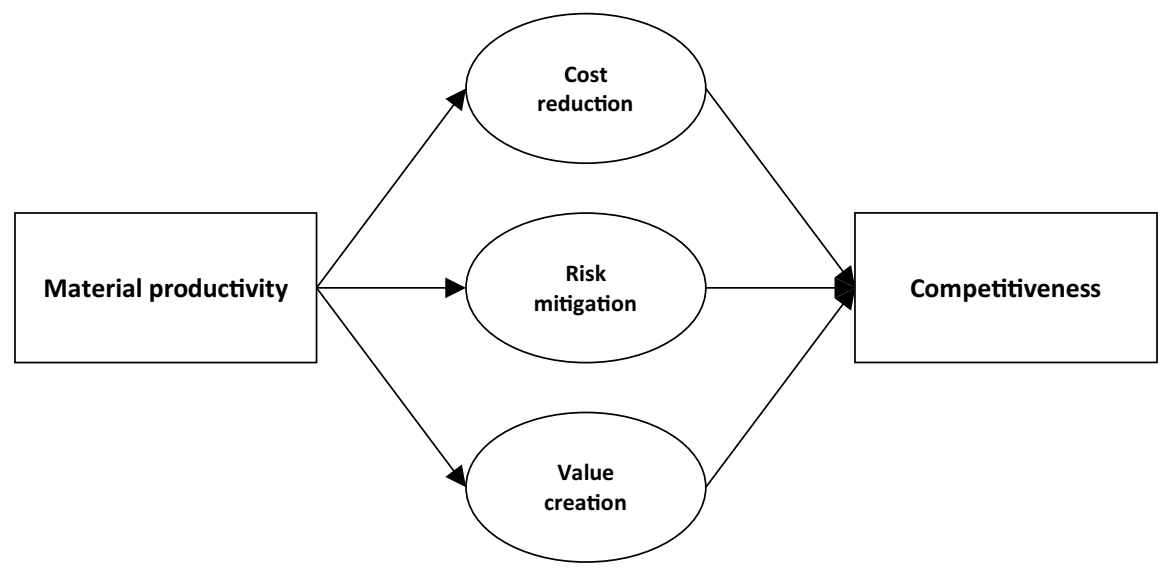

Fig. 1 Channels linking material productivity and competitiveness

\section{References}

Acemoglu D, Johnson S (2007) Disease and development: the effect of life expectancy on economic growth. J Polit Econ 115:925-985. https://doi.org/10.1086/529000

Aghion P, Bloom N, Blundell R et al (2005) Competition and innovation: an inverted-U relationship. Q J Econ 120:701-728

Aiginger K (2006) Competitiveness: from a dangerous obsession to a welfare creating ability with positive externalities. J Ind Compet Trade 6:161-177. https://doi.org/10.1007/s10842-006-9475-6

Aiginger K, Vogel J (2015) Competitiveness: from a misleading concept to a strategy supporting beyond GDP goals. Compet Rev 25:497-523. https://doi.org/10.1108/cr-06-2015-0052

AMEC, Bio IS (2013) The opportunities to business of improving resource efficiency. AMEC, Bio IS, Cheshire

Angrist JD, Krueger AB (2001) Instrumental variables and the search for identification: from supply and demand to natural experiments. J Econ Perspect 15:69-85. https://doi.org/10.1257/jep.15.4.69

Angrist JD, Pischke J-S (2009) Mostly harmless econometrics: an empiricist' s companion. Princeton University Press, Princeton

Angrist JD, Imbens GW, Rubin DB (1996) Identification of causal effects using instrumental. J Am Stat Assoc 91:444-455

Arrow K, Bolin B, Costanza R et al (1995) Economic growth, carrying capacity, and the environment. Ecol Econ 15:91-95. https://doi.org/10.1016/0921-8009(95)00059-3

Bahn-Walkowiak B, Steger S (2015) Resource targets in Europe and worldwide: an overview. Resources 4:597-620. https://doi.org/10.3390/resources4030597

Baldwin RE, Robert-Nicoud F (2008) Trade and growth with heterogeneous firms. J Int Econ 74:21-34. https://doi.org/10.1016/j.jinteco.2007.05.004

Bassi AM, Tan Z, Mbi A (2012) Estimating the impact of investing in a resource efficient, resilient global energy-intensive manufacturing industry. Technol Forecast Soc Change 79:69-84. https://doi. org/10.1016/j.techfore.2011.05.011

Bertrand M, Mullainathan S (2001) Do people mean what they say? Implications for subjective survey data. Am Econ Rev 91:67-72. https://doi.org/10.2139/ssrn.260131

Black J, Hashimzade N, Myles G (2013) Oxford dictionary of economics. A Dict Econ (4 ed). doi: Online Version: 2012 eISBN: 9780191726842

Blanes JV, Busom I (2004) Who participates in R\&D subsidy programs? The case of Spanish manufacturing firms. Res Policy 33:1459-1476. https://doi.org/10.1016/j.respol.2004.07.006

Bleischwitz R, Giljum S, Kuhndt M, Schmidt-Bleek F (2009a) Eco-innovation-putting the EU on the path to a resource and energy efficient economy. Wuppertal Spezial Issue 38. Wuppertal, Germany 
Bleischwitz R, Steger S, Onischka M, Bahn-Walkowiak B (2009b) Potenziale der Materialeffizienz erschließen. Okologisches Wirtschaften. Ökologisches Wirtschaften 2:35-39

Bound J, Jaeger DA, Baker RM (1995) Problems with instrumental variables estimation when the correlation between the instruments and the endogenous explanatory variable is weak. J Am Stat Assoc 90:443-450. https://doi.org/10.1080/01621459.1995.10476536

Bruyn S, Markowska A, de Jong F, Blom M (2009) Resource productivity, competitiveness and environment policies. Delft, The Netherlands

Busom I (2000) An empirical evaluation of the effects of R\&D subsidies. Econ Innov New Technol 9:111-148. https://doi.org/10.1080/10438590000000006

Calantone RJ, Cavusgil ST, Zhao Y (2002) Learning orientation, firm innovation capability, and firm performance. Ind Mark Manag 31:515-524. https://doi.org/10.1016/s0019-8501(01)00203-6

Caloghirou Y, Kastelli I, Tsakanikas A (2004) Internal capabilities and external knowledge sources: complements or substitutes for innovative performance? Technovation 24:29-39. https://doi. org/10.1016/s0166-4972(02)00051-2

Chan HS, Li S, Zhang F (2013) Firm competitiveness and the European Union emissions trading scheme. Energy Policy 63:1056-1064. https://doi.org/10.1016/j.enpol.2013.09.032

Cohen WM, Levinthal DA (1990) Absorptive-capacity - a new perspective on learning and innovation. Adm Sci Q 35:128-152. https://doi.org/10.2307/2393553

Cooper S, Skelton ACH, Owen A et al (2016) A multi-method approach for analysing the potential employment impacts of material efficiency. Resour Conserv Recycl 109:54-66. https://doi. org/10.1016/j.resconrec.2015.11.014

Czarnitzki D, Wastyn A (2010) Competing internationally: on the importance of R\&D for export activity. ZEW Discuss Pap 10:1-36

Dahlstrom K, Ekins P (2005) Eco-efficiency trends in the UK steel and aluminum industries and resource productivity. J Ind Ecol 9:171-188

Dechezleprêtre A, Sato M (2014) The impacts of environmental regulations on competitiveness. Grantham Res Inst Clim Chang Environ Glob Green Growth Inst. https://doi.org/10.1086/342808

Dell M, Jones BF, Olken BA (2012) Temperature shocks and economic growth: evidence from the last half century. Am Econ J Macroecon 4:66-95

Dinkelman T (2011) The effects of rural electrification on employment: new evidence from South Africa. Am Econ Rev 101:3078-3108

Distelkamp M, Meyer B, Meyer M (2010) Quantitative und qualitative Analyse der ökonomischen Effekte einer forcierten Ressourceneffizienzstrategie Abschlussbericht zu AP5. Wuppertal, Germany

Dosi G, Grazzi M, Moschella D (2015) Technology and costs in international competitiveness: from countries and sectors to firms. Res Policy 44:1795-1814. https://doi.org/10.1016/j.respo 1.2015 .05 .012

Dussaux D, Glachant M (2015) How much does recycling reduce imports? Evidence from metallic raw materials (working paper). Paris, France

Ebrahim Z, Inderwildi OR, King DA (2014) Macroeconomic impacts of oil price volatility: mitigation and resilience. Front Energy 8:9-24. https://doi.org/10.1007/s11708-014-0303-0

EBRD (2015) Green economy transition approach. London, UK

EC (2008) The raw materials initiative - meeting our critical needs for growth and jobs in Europe COM (2008) 699 final. The European Commission, Brussels

EC (2010) Critical raw materials for the EU—report of the ad hoc working group on defining critical raw materials. The European Commission, Belgium

EC (2011a) Roadmap to a resource efficient Europe-COM(2011) 571 final. The European Commission, Brussels

EC (2011b) Attitudes of European entrepreneurs towards eco-innovation. Flash Eurobarometer 315. Brussels, Belgium

EC (2013) Business economy-structural profile. The European Commission, Luxembourg

EC (2014a) Report on critical raw materials for the EU, report of the ad hoc working group on defining critical raw materials

EC (2014b) Study on modelling of the economic and environmental impacts of raw material consumption. The European Commission, Belgium

EC (2014c) An investment plan for Europe-COM(2014) 903 final. European Commission, Brussels

EC (2015a) Closing the loop-an EU action plan for the circular economy-COM(2015) 614/2. https:// doi.org/10.1017/cbo9781107415324.004

EC (2015b) Glossary of DG Eurostat. European Commission, Luxembourg 
EC (2015c) User guide to the SME definition—Ref. Ares(2016)956541-24/02/2016. Brussels, Belgium

Ecorys (2011) Study on the competitiveness of the European companies and resource efficiency. Ecorys, Rotterdam

EEA (2011) Earnings, jobs and innovation: the role of recycling in a green economy. EEA, Copenhagen

EIB (2015) The EIB in the circular economy. EIB, Luxembourg

Ekins P, Speck S (2010) Competitiveness and environmental tax reform

EU (2012) The treaty on the functioning of the European Union. European Union, Belgium

Fh-ISI, Wuppertal Institute, Arthur D. Little GmbH (2005) Studie zur Konzeption eines Programms für die Steigerung der Materialeffizienz in mittelständischen Unternehmen. Wiesbaden, Germany

Fischer S, Brien MO (2012) Eco-innovation in business: reducing cost and increasing profitability via material efficiency measures. Wuppertal, Germany

Flachenecker F (2015) Sustainability, resource efficiency and competitiveness an assessment of resource efficiency policies in the European Union. Bruges Eur Econ Res Pap 32:1-33

Flachenecker F (2018) The causal impact of material productivity on macroeconomic competitiveness in the European Union. Environ Econ Policy Stud 20:17-46. https://doi.org/10.1007/s1001 8-016-0180-3

Flachenecker F, Rentschler JE (2015) Investments in resource efficiency-costs and benefits, investment barriers, intervention measures. London, UK, UK

Font Vivanco D, Kemp R, van der Voet E (2016) How to deal with the rebound effect? A policy-oriented approach. Energy Policy 94:114-125. https://doi.org/10.1016/j.enpol.2016.03.054

Galdeano-Gómez E (2008) Does an endogenous relationship exist between environmental and economic performance? A resource-based view on the horticultural sector. Environ Resour Econ 40:73-89. https://doi.org/10.1007/s10640-007-9141-4

Ghisetti C, Mancinelli S, Mazzanti M, Zoli M (2016) Financial barriers and environmental innovations: evidence from EU manufacturing firms. Clim Policy. https://doi.org/10.1080/14693 062.2016.1242057

Gilbert P, Wilson P, Walsh C, Hodgson P (2016) The role of material efficiency to reduce $\mathrm{CO}_{2}$ emissions during ship manufacture: a life cycle approach. Mar Policy 75:227-237. https://doi.org/10.1016/j. marpol.2016.04.003

Gunningham N, Kagan R, Thornton D (2004) Social license and environmental protection: why businesses go beyond compliance. Law Soc Inq 307:1-37

Hall BH (1987) The relationship between firm size and firm growth in the US manufacturing sector. J Ind Econ 35:583-606

Harris R, Moffat J (2011) R\&D, innovation and exporting-SERC DISCUSSION PAPER 73. Glasgow, UK

Hashi I, Stojčić N (2013) The impact of innovation activities on firm performance using a multi-stage model: evidence from the Community Innovation Survey 4. Res Policy 42:353-366. https://doi. org/10.1016/j.respol.2012.09.011

Hinterberger F, Giljum S, Hammer M (2003) Material flow accounting and analysis (MFA)—a valuable tool for analyses of society-nature interrelationships. SERI Background Paper. Vienna, Austria

Hoang V-N (2014) Analysis of resource efficiency: a production frontier approach. J Environ Manag 137:128-136

Horbach J (2014) Determinants of eco-innovation from a European-wide perspective—an analysis based on the community innovation survey (CIS). Seeds Work. Pap. Ser. 7

Horbach J, Rennings K (2013) Environmental innovation and employment dynamics in different technology fields - an analysis based on the German Community Innovation Survey 2009. J Clean Prod 57:158-165. https://doi.org/10.1016/j.jclepro.2013.05.034

IEA (2014) Capturing the multiple benefits of energy efficiency. France, Paris

Imbens GW, Angrist JD (1994) Identification and estimation of local average treatment effects. Econometrica 62:467-475

Jaffe AB, Peterson S, Portney P, Stavins R (1996) Environmental regulation and the competitiveness of US manufactoring: what does the evidence tell us? J Econ Lit 12:658-712

Jordan ND, Lemken T, Liedtke C (2014) Barriers to resource efficiency innovations and opportunities for smart regulations-the case of Germany. Environ Policy Gov 24:307-323. https://doi.org/10.1002/ eet. 1632

Kemp R, Diaz Lopez FJ, Bleischwitz R (2013) Report on green growth and eco-innovation. Wuppertal, Germany 
KfW (2009) Perspektive Zukunftsfähigkeit-Steigerung der Rohstoff- und Materialeffizienz. KfW Research, Frankfurt

Khandker SR, Samad HA, Ali R, Barnes DF (2014) Who benefits most from rural electrification? Evidence in India. Energy J 35:75-96. https://doi.org/10.5547/01956574.35.2.4

Kraay A (2012) Instrumental variables regressions with uncertain exclusions restrictions: a Bayesian approach. J Appl Econom 27:108-128. https://doi.org/10.1002/jae.1148

Krugman P (1994) Competiveness a Dangerous obsession. Foreign Aff 73:28-44

Lachenmaier S, Wößmann L (2006) Does innovation cause exports? Evidence from exogenous innovation impulses and obstacles using German micro data. Oxf Econ Pap 58:317-350. https://doi. org/10.1093/oep/gpi043

Lankoski L (2010) Linkages between environmental policy and competitiveness. OECD Environ Work Pap. https://doi.org/10.1787/218446820583

Larrán Jorge M, Herrera Madueño J, Martínez-Martínez D, Lechuga Sancho MP (2015) Competitiveness and environmental performance in Spanish small and medium enterprises: is there a direct link? J Clean Prod 101:26-37. https://doi.org/10.1016/j.jclepro.2015.04.016

Lehner F, Bierter W, Charles T (1999) Resource productivity, competitiveness, and employment in the advanced economies. Factor 10:105-133

Lööf H, Johansson B (2009) Innovation, R\&D and productivity: assessing alternative specifications of CDM-models. CESIS 1-34

Machiba T (2010) Eco-innovation for enabling resource efficiency and green growth: development of an analytical framework and preliminary analysis of industry and policy practices. Int Econ Econ Policy 7:357-370. https://doi.org/10.1007/s10368-010-0171-y

Malerba F (1992) Learning by firms and incremental technical change. Econ J 102:845-859

Maskell P, Malmberg A (1999) Localised learning and industrial competitiveness. Camb J Econ 23:167-185

Meyer B (2011) Macroeconomic modelling of sustainable development and the links between the economy and the environment - a report prepared for the European Commission. DG Environment, Osnabruck

Oakdene Hollins (2011) The further benefits of business resource efficiency. A research report completed for the Department for Environment, Food and Rural Affairs. London, UK

OECD (2007) Measuring material flows and resource productivity—Volume I: the OECD Guide. Paris, France

OECD (2016) Policy guidance on resource efficiency. OECD Publishing, Paris. https://doi. org/10.1787/9789264257344-en

Panizza U, Presbitero AF (2014) Public debt and economic growth: is there a causal effect? J Macroecon 41:21-41. https://doi.org/10.1016/j.jmacro.2014.03.009

Pindyck RS (2007) Uncertainty in environmental economics. Rev Environ Econ Policy 1:45-65. https:// doi.org/10.1093/reep/rem002

Porter M (1990) The competitive advantage of nations. Harv Bus Rev 68:1-18

Porter M, Van Der Linde C (1995) Toward a new conception of the environment-competitiveness relationship. J Econ Perspect 9:97-118

Reed WR (2015) On the practice of lagging variables to avoid simultaneity. Oxf Bull Econ Stat 77:897905. https://doi.org/10.1111/obes.12088

Reinert ES (1995) Competitiveness and its predecessors-a 500-year cross-national perspective. Struct Chang Econ 6:23-42

Rennings K, Rammer C (2009) Increasing energy and resource efficiency through innovation: an explorative analysis using innovation survey data. Czech J Econ Financ 59:442-459

Rockström J, Steffen W, Noone K et al (2009) A safe operating space for humanity. Nature 461:472-475. https://doi.org/10.1038/461472a

Rubashkina Y, Galeotti M, Verdolini E (2015) Environmental regulation and competitiveness: empirical evidence on the Porter Hypothesis from European manufacturing sectors. Energy Policy 83:288300. https://doi.org/10.1016/j.enpol.2015.02.014

Sakamoto T, Managi S (2017) New evidence of environmental efficiency on the export performance. Appl Energy 185:615-626. https://doi.org/10.1016/j.apenergy.2016.10.126

Schmidt M, Schneider M (2010) Kosteneinsparungen durch Ressourceneffizienz in produzierenden Unternehmen. Umweltwirtschaftsforum 18:153-164. https://doi.org/10.1007/s00550-010-0182-8 
Schröter M, Lerch C, Jäger A (2011) Materialeffizienz in der Produktion: Einsparpotenziale und Verbreitung von Konzepten zur Materialeinsparung im Verarbeitenden Gewerbe. A report prepared for the German Federal Ministry of the Economy and Technology. Karlsruhe, Germany

Shahbazi S, Wiktorsson M, Kurdve M et al (2015) Material efficiency in manufacturing: Swedish evidence on potential, barriers and strategies. J Clean Prod 127:438-450. https://doi.org/10.1016/j. jclepro.2016.03.143

Siggel E (2006) International competitiveness and comparative advantage: a survey and a proposal for measurement. J Ind Compet Trade 6:137-159. https://doi.org/10.1007/s10842-006-8430-x

Snowdon B, Stonehouse G (2006) Competitiveness in a globalised world: Michael Porter on the Microeconomic Foundations of the competitiveness of nations, regions, and firms. J Int Bus Stud 37:163-175

Statistisches Bundesamt (2011) Statistisches Jahrbuch 2011. Wiesbaden, Germany

Steinberger JK, Krausmann F (2011) Material and energy productivity. Environ Sci Technol 45:11691176. https://doi.org/10.1021/es1028537

Stock JH, Yogo M (2002) Testing for weak instruments in linear IV regression-technical working paper 284. Cambridge, USA

Syverson C (2011) What determines productivity? J Econ Lit 49:326-365

Tilton JE (2001) Depletion and the long-run availability of mineral commodities. Colorado, USA

Tilton JE (2003) Assessing the threat of mineral depletion. Miner Energy Raw Mater Rep 18:33-42. https ://doi.org/10.1080/14041040310008383

Triebswetter U, Wackerbauer J (2008) Integrated environmental product innovation in the region of Munich and its impact on company competitiveness. J Clean Prod 16:1484-1493. https://doi. org/10.1016/j.jclepro.2007.09.003

UNEP IRP (2011) Decoupling: natural resource use and environmental impacts from economic growth. Nairobi, Kenya

UNEP IRP (2014) Decoupling 2-technologies, opportunities and policy options. Nairobi, Kenya

Videras J, Alberini A (2000) The appeal of voluntary environmental programs: which firms participate and why? Contemp Econ Policy 18:449-461. https://doi.org/10.1111/j.1465-7287.2000.tb00041.x

Wagner M, Hong SH (2016) Cointegrating polynomial regressions: fully modified Ols estimation and inference. Econom Theory 32:1289-1315. https://doi.org/10.1017/s0266466615000213

Walz R (2011) Employment and structural impacts of material efficiency strategies: results from five case studies. J Clean Prod 19:805-815. https://doi.org/10.1016/j.jclepro.2010.06.023

Wiedmann TO, Schandl H, Moran D (2015) The footprint of using metals: new metrics of consumption and productivity. Environ Econ Policy Stud 17:369-388. https://doi.org/10.1007/s1001 8-014-0085-y

Wilting H, Hanemaaijer A (2014) Share of raw material costs in total production costs

Wooldridge JM (2002) Econometric analysis of cross section and panel data. MIT Press, London. https:// doi.org/10.1515/humr.2003.021

Yasuda T (2005) Firm growth, size, age and behavior in Japanese manufacturing. Small Bus Econ 24:115. https://doi.org/10.1007/s11187-005-7568-y

Zhao L, Zhang X, Wang S, Xu S (2013) The effects of oil price shocks on output and inflation in China. Energy Econ 53:101-110. https://doi.org/10.1016/j.eneco.2014.11.017 